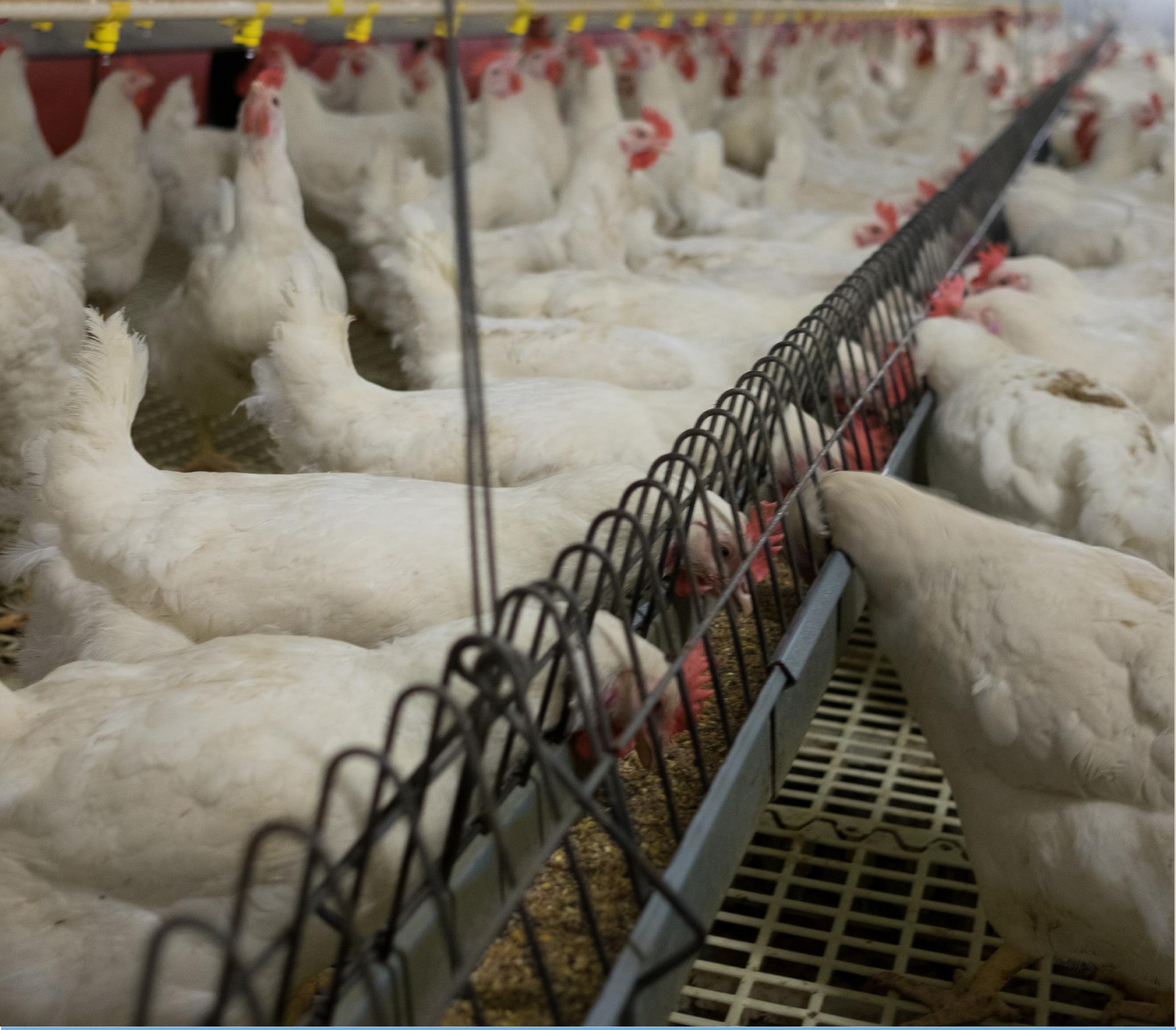

Het effect van twice-a-day-feeding en splitfeeding op reproductie, eischaalkwaliteit en gedrag van vleeskuikenouderdieren

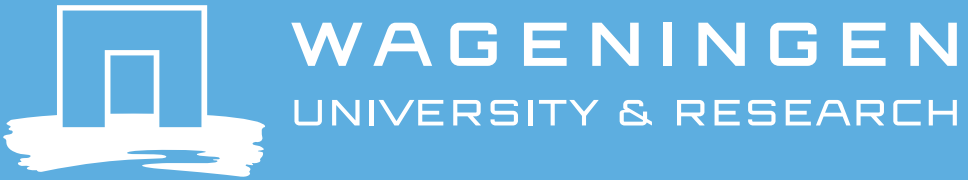





\section{Het effect van twice-a-day-feeding en splitfeeding op reproductie, eischaalkwaliteit en gedrag van vleeskuikenouderdieren}

Rick van Emous ${ }^{1}$, Gisabeth Binnendijk ${ }^{1}$ en Henk Gunnink ${ }^{1}$

${ }^{1}$ Wageningen Livestock Research

Dit onderzoek is uitgevoerd door Wageningen Livestock Research binnen het kader van de Publiek Private Samenwerking (PPS) "Breeders In Technology" (BITe) (BO-63-001-033). Dit project is een samenwerking tussen het Ministerie van Landbouw, Natuur en Voedselkwaliteit en een consortium van verschillende partijen. 
R.A. van Emous, G.P. Binnendijk en H. Gunnink, 2021. Het effect van twice-a-day feeding en splitfeeding op redproductie, eischaalkwaliteit en gedrag van vleeskuikenouderdieren. Wageningen Livestock Research, Rapport 1338.

In dit rapport worden de resultaten gepresenteerd van een studie naar het toepassen van split-feeding (= verschillend ochtend- en middagvoer) en twice-a-day-feeding ( $=2$ keer per dag eenzelfde standaard voer) ten opzichte van eenmaal daags voeren (standaard voer) bij vleeskuikenouderdieren tijdens de late legperiode (van 45-65 weken leeftijd). Dit experiment is uitgevoerd in opdracht van het Consortium Breeders In Technology (BITe) en het Ministerie van Landbouw, Natuur en Voedselkwaliteit.

Uit het onderzoek blijkt dat de dieren die het split-feeding programma volgden tussen 45 en 65 weken leeftijd een hogere productie en lagere uitval hadden. Daarnaast werden bij de tweemaal daags gevoerde dieren (twice-a-day-feeding en split-feeding) een lagere wateropname en lagere water/voerverhouding gevonden. Het toepassen van tweemaal daags voeren (twice-a-day-feeding en splitfeeding) had nauwelijks effect op broedeikwaliteit en geen effect op de broederijresultaten. Bij de tweemaal ten opzichte van eenmaal daags gevoerde dieren werd een ander gedragspatroon gedurende de dag waargenomen. De tweemaal daags gevoerde dieren kregen tweemaal daags een halve portie voer, hetgeen de belangrijkste factor was voor de verschillen in het gedragspatroon. Het was niet helemaal eenduidig maar de tweemaal daags gevoerde dieren (twice-a-day-feeding en splitfeeding) vertoonden in gemiddeld: minder drinken, meer staan, minder zitten, meer lopen en minder foerageren.

Dit rapport is gratis te downloaden op https://doi.org/10.18174/554347 of op www.wur.nl/livestockresearch (onder Wageningen Livestock Research publicaties).

\section{(cc) BY-NC}

Dit werk valt onder een Creative Commons Naamsvermelding-Niet Commercieel 4.0 Internationaallicentie.

(C) Wageningen Livestock Research, onderdeel van Stichting Wageningen Research, 2021

De gebruiker mag het werk kopiëren, verspreiden en doorgeven en afgeleide werken maken. Materiaal van derden waarvan in het werk gebruik is gemaakt en waarop intellectuele eigendomsrechten berusten, mogen niet zonder voorafgaande toestemming van derden gebruikt worden. De gebruiker dient bij het werk de door de maker of de licentiegever aangegeven naam te vermelden, maar niet zodanig dat de indruk gewekt wordt dat zij daarmee instemmen met het werk van de gebruiker of het gebruik van het werk. De gebruiker mag het werk niet voor commerciële doeleinden gebruiken.

Wageningen Livestock Research aanvaardt geen aansprakelijkheid voor eventuele schade voortvloeiend uit het gebruik van de resultaten van dit onderzoek of de toepassing van de adviezen.

Wageningen Livestock Research is NEN-EN-ISO 9001:2015 gecertificeerd.

Op al onze onderzoeksopdrachten zijn de Algemene Voorwaarden van de Animal Sciences Group van toepassing. Deze zijn gedeponeerd bij de Arrondissementsrechtbank Zwolle. 


\section{Inhoud}

$\begin{array}{ll}\text { Woord vooraf } & 5\end{array}$

$\begin{array}{ll}\text { Samenvatting } & 7\end{array}$

1

Inleiding

2

Materiaal en methoden $\quad 13$

2.1 Dieren 13

2.2 Huisvesting en verzorging 13

$\begin{array}{lll}2.3 & \text { Experimentele opzet } & 14\end{array}$

$\begin{array}{lll}2.4 & \text { Waarnemingen } & 15\end{array}$

2.4.1 Analyses grondstoffen en voeders $\quad 15$

2.4.2 Lichaamsgewicht hennen en hanen $\quad 15$

$\begin{array}{ll}2.4 .3 \text { Productieresultaten } & 15\end{array}$

2.4.4 Broederijresultaten $\quad 15$

2.4.5 Broedeikwaliteit 16

$\begin{array}{ll}2.4 .6 \text { Gedrag } & 17\end{array}$

$\begin{array}{ll}2.4 .7 \text { Bevedering } & 17\end{array}$

$\begin{array}{lll}2.5 & \text { Statistische analyse } & 17\end{array}$

$\begin{array}{llr}3 & \text { Resultaten } & 18\end{array}$

$\begin{array}{lll}3.1 & \text { Verloop experiment } & 18\end{array}$

$\begin{array}{lll}3.2 & \text { Analyse voeders } & 22\end{array}$

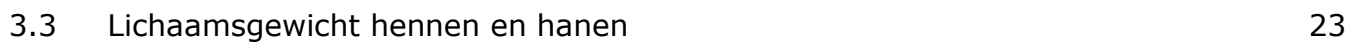

$\begin{array}{lll}3.4 & \text { Productieresultaten } & 24\end{array}$

$\begin{array}{lll}3.5 & \text { Broederijresultaten } & 25\end{array}$

$\begin{array}{lll}3.6 & \text { Broedeikwaliteit } & 26\end{array}$

$\begin{array}{lll}3.7 & \text { Bevedering } & 28\end{array}$

3.8 Gedrag 29

3.8.1 Algemeen 29

$\begin{array}{ll}3.8 .2 \text { Gedragspatroon } & 30\end{array}$

4

$\begin{array}{ll}\text { Discussie } & 33\end{array}$

4.1 Effect voerstrategieën op productieresultaten 33

$\begin{array}{lll}4.2 & \text { Effect voerstrategie op broederijresultaten } & 34\end{array}$

4.3 Effect voerstrategie op broedeikwaliteit $\quad 34$

4.4 Effect voerstrategie op bevedering $\quad 34$

$\begin{array}{lll}4.5 & \text { Effect voerstrategie op gedrag } & 34\end{array}$

$\begin{array}{llr}5 & \text { Conclusies } & 36\end{array}$

$\begin{array}{ll}\text { Literatuur } & 37\end{array}$

$\begin{array}{lll}\text { Bijlage } 1 \text { Schematisch overzicht hok } & 39\end{array}$

$\begin{array}{lll}\text { Bijlage } 2 & \text { Samenstelling voeders } & 40\end{array}$

$\begin{array}{lll}\text { Bijlage } 3 & \text { Ethogram gedrag } & 41\end{array}$ 


\section{Woord vooraf}

Vleeskuikenouderdieren veranderen in de loop van de tijd door aanpassingen aan de fokdoelen, waardoor ook aanpassingen nodig kunnen zijn aan de houderij en het management van deze dieren. De persistentie van de productie en bevruchting van het huidige vleeskuikenouderdier is verbeterd in vergelijking met ouderdieren van 10 tot 20 jaar geleden. Daardoor is het idee ontstaan om de dieren langer aan te houden dan de gebruikelijke 60 weken leeftijd. Een langere productieperiode is een stap voorwaarts naar een duurzamere houderij van vleeskuikenouderdieren. Er worden minder dieren opgezet, ze leven langer, hebben een lagere arbeidsbehoefte, hebben een verhoogde productie per dier, etc. Deze zaken passen allemaal in een transitie naar een nieuwe manier van het houden van vleeskuikenouderdieren die toekomstbestendig is.

In dit rapport worden de resultaten gepresenteerd van een experiment met vleeskuikenouderdieren waarbij de dieren verschillende voerstrategieën kregen. Het onderzoek richtte zich op de tweede helft van de legperiode (vanaf 45 weken leeftijd) waarbij de dieren ook langer dan gebruikelijk werden aangehouden (tot 65 weken leeftijd). Deze studie is uitgevoerd door Wageningen Livestock Research in opdracht van, en gefinancierd door het Consortium Breeders In Technology en het Ministerie van Landbouw, Natuur en Voedselkwaliteit. Het hier beschreven onderzoek kan bijdragen aan aangepast management om vleeskuikenouderdieren langer aan te houden.

De auteurs bedanken de partners (Ministerie van LNV, PLUIMNED (Stuurgroep opfok en vermeerdering LTO/NOP en NVP), ABZ Diervoeding, Aviagen-EPI, De Heus Voeders, De Hoop Mengvoeders, EW Nutrition, ForFarmers, Hubbard, Trouw Nutrition, Sommen, Veterinair Centrum Someren en HAS Hogeschool) binnen het project Breeders In Technology voor de prettige samenwerking.

Projectleider

Dr. ing. R.A. (Rick) van Emous 


\section{Samenvatting}

\section{Aanleiding en doel}

De toenemende persistentie ten aanzien van productie en bevruchting bij vleeskuikenouderdieren was de aanleiding om onderzoek te initiëren om de dieren langer dan gebruikelijk (tot 65 weken leeftijd) aan te houden. Het verlengen van de legperiode is interessant omdat de aankoopkosten van de opfokdieren verdeeld kunnen worden over een langere productieperiode, er meer eieren per dier geproduceerd worden en er minder arbeid nodig is voor vaccinatie, laden en reinigen. Als basis voor het verlengen van de legperiode bij ouderdieren is gekeken naar de kennis die de laatste jaren is opgedaan in de leghennensector. Daar heeft men al jaren ervaring met het verlengen van de legperiode en worden de leghennen in het laatste decennium gemiddeld een week per jaar langer gehouden. Bij leghennen wordt de transitie naar een langere productieperiode ondersteund door verschillende experimenten en daaruit volgende aanpassingen aan het management. Een van de onderzoeksrichtingen is het toepassen van split-feeding, waarbij de dieren een op de specifieke behoeften aangepast ochtend- en middagvoer verstrekt krijgen. Bij vleeskuikenouderdieren is tot nu toe echter nauwelijks onderzoek uitgevoerd naar het verlengen van de productieperiode, en ook niet naar split-feeding.

Het doel van het onderzoek was om de effecten te bestuderen van split-feeding en twice-a-dayfeeding ten opzichte van het eenmaal per dag verstrekken van standaard voer op de reproductie, eischaalkwaliteit en het gedrag van vleeskuikenouderdieren.

\section{Dieren, huisvesting en verzorging}

De proef werd uitgevoerd met ouderdieren tussen 45 en 65 weken leeftijd, met 30 hennen en 1 haan per hok (Ross 308). De dieren waren afkomstig van een praktijkbedrijf en werden op 44 weken leeftijd overgeplaatst naar de onderzoek accommodatie, waarna de dieren een week konden wennen aan de nieuwe omgeving. De dieren werden gehouden in twee afdelingen met elk twaalf hokken ( 24 hokken in totaal). De hokken waren elk 2,5 bij 2,0 meter $\left(5 \mathrm{~m}^{2}\right)$. Er was een houten rooster (150 bij $100 \mathrm{~cm}$ ) geïnstalleerd met aangrenzend buiten het hok een legnest $(90 \times 40 \mathrm{~cm})$. Verder waren per hok twee kunststof zitstokken (rechthoekig met afgeronde hoeken) met een totale lengte van 4 meter geïnstalleerd. De voervoorziening voor de hennen bevond zich in de strooiselruimte, middels twee voergoten met grill (totaal 3,7 m lengte) per hok. De hanen werden ook in de strooiselruimte gevoerd met een aparte voerbak op $50 \mathrm{~cm}$ hoogte. Water werd gedurende de lichtperiode ad libitum verstrekt via een drinknippellijn (zeven nippels) welke zich boven het rooster bevond. In de namiddag (15.00 uur) kregen de dieren twee gram/dier strooigraan in het strooisel verstrekt. De lichtperiode stond ingesteld op 14 uur licht (07.00 tot 21.00 uur) en de lichtsterkte was minimaal 40 lux op kophoogte. Gedurende het experiment was de streefwaarde voor ruimtetemperatuur ingesteld op $20^{\circ} \mathrm{C}$.

\section{Experimentele opzet}

In dit experiment werden drie verschillende behandelingen (voerstrategieën) toegepast, elk met 8 herhalingen. De eerste groep dieren kreeg eenmaal daags (07.30 uur) controlevoer (CON) (= standaard foktoomvoer 3). De tweede groep dieren kreeg tweemaal daags ( $50 \%$ om 07.30 uur en $50 \%$ om 16.00 uur) controlevoer (= standaard foktoomvoer 3 ) verstrekt (twice-a-day-feeding = TAD). De derde groep dieren kreeg tweemaal daags ( 07.30 en 16.00 uur) twee verschillende voersoorten verstrekt (split-feeding $=\mathbf{S F}$ ). Het ochtendvoer bevatte meer energie, eiwit en fosfor ( $P$ ) en minder calcium ( $\mathrm{Ca}$ ) dan controle- en middagvoer (Bijlage 2). Het middagvoer had een lager gehalte aan energie, eiwit en $\mathrm{P}$ en een hoger gehalte aan Ca ten opzichte van het controle- en het ochtendvoer. Om verstrengeling van behandelingen te voorkomen werden de voeders zo samengesteld dat de gemiddelde nutritionele waarde van het ochtend- en middagvoer vergelijkbaar was met het controlevoer. Daarnaast bestond het ochtendvoer uit $80 \%$ fijne calciumbron (krijt) en $20 \%$ grove calciumbron (kalksteentjes grof) terwijl het middagvoer bestond uit $80 \%$ grove calciumbron en $20 \%$ fijne calciumbron. Dit werd gedaan om in de ochtend de calciumvoorraad in het skelet snel aan te vullen en in de middag om de aanmaak van de eischaal gedurende de avond en nacht zoveel mogelijk te faciliteren doordat een grove calciumbron langzamer ter beschikking komt. 
De dieren kregen het voer (07.30 uur) vrijwel direct nadat het licht was aangegaan (07.00 uur) verstrekt. Dit is gedaan omdat dit meer overeen komt met de huidige methode van voer verstrekken in de praktijk. De meeste bedrijven voeren 's nachts direct nadat het licht aangaat. De hanen werden eenmaal daags 's morgens direct na de hennen gevoerd.

De dieren kregen een vooraf bepaalde voerhoeveelheid verstrekt zodat alle dieren in de verschillende behandelingen hetzelfde gewichtsschema volgden (Aviagen-EPI, 2017).

\section{Waarnemingen}

De volgende waarnemingen werden verricht:

- De belangrijkste ingrediënten en de geproduceerde voeders werden geanalyseerd op droge stof, ruw eiwit, ruw vet, ruwe celstof, ruw as, zetmeel, suikers, Ca en $P$.

- Wekelijks werd het lichaamsgewicht van de hennen (steekproef van tien stuks) en de haan per hok vastgesteld.

- Dagelijks werden de volgende productieresultaten verzameld: voergift, wateropname, uitval, eiproductie en uitsortering tweede soort eieren.

- Eenmaal per week werd het eigewicht bepaald van de $1^{\mathrm{e}}$ soort broedeieren.

- Op 52, 59 en 65 weken leeftijd werden 50 broedeieren per hok verzameld en zeven dagen bebroed om de bevruchting en embryonale sterfte na deze periode te bepalen.

- Bij vijftien $1^{\mathrm{e}}$ soort broedeieren per hok werd op 45 (nulmeting), 50, 55, 60 en 65 weken leeftijd de breuksterkte en eischaaldikte gemeten.

- Van vijftien $1^{\mathrm{e}}$ soort broedeieren per hok werd op 45, 50, 55, 60 en 65 weken leeftijd het soortelijk gewicht (Specific Gravity) bepaald.

- Van tien $1^{\mathrm{e}}$ soort broedeieren per hok werden op 45, 50, 55, 60 en 65 weken leeftijd de albumen/dooier verhouding, eischaalgewicht en drogestofgehalte eischaal bepaald.

- Het gedrag van de hennen werd op 45, 50 55, 60 en 65 weken leeftijd geobserveerd met behulp van scansampling. Waarnemingen vonden plaats gedurende de lichtperiode, in twaalf observatieronden per waarnemingsdag.

- De bevedering werd op 45, 50 55, 60 en 65 weken leeftijd van vijf dieren per hok beoordeeld.

\section{Resultaten}

Tijdens het experiment werden onderstaande resultaten waargenomen.

Algemeen:

- Het experiment is zonder verstoringen verlopen en de dieren produceerden ten opzichte van de norm bijna 18 eieren meer in de 20 weekse experimentele periode.

- Het percentage grondeieren was met meer dan $7 \%$ aan de hoge kant.

- De uitval bij de hennen was tweemaal hoger (0,4 vs. 0,2\% per week) dan de praktijk.

- Ondanks slechts 1 haan per 29 hennen lag de gemiddelde praktijk bevruchting rond de $90 \%$.

Analyse voeders:

- De geanalyseerde waarde van het ruw eiwitgehalte week gemiddeld nauwelijks af van de berekende waarde.

- De geanalyseerde calciumgehalten in het controle- en middagvoer waren respectievelijk 5,4 en $4,6 \%$ lager dan de berekende gehalten. Het geanalyseerde calciumgehalte in het ochtendvoer was $3,8 \%$ hoger dan het berekende gehalte.

- De geanalyseerde fosforgehalten in het controle-, ochtend- en middagvoer waren respectievelijk $7,4,0,7$ en $6,6 \%$ lager dan de berekende gehalten.

- Ondanks de verschillen in berekende en geanalyseerde waarden bleef het gewenste contrast tussen de voeders aanwezig.

Lichaamsgewicht hennen en hanen:

- Er waren tussen de behandelingen geen verschillen in het lichaamsgewicht van de hennen en hanen tijdens het experiment.

Productieresultaten:

- Er waren geen verschillen in voergift tussen de verschillende voerstrategieën.

- De dieren die tweemaal per dag gevoerd werden (twice-a-day feeding en split-feeding) dronken minder en hadden een lagere water/voer-verhouding dan de dieren die eenmaal per dag gevoerd werden. 
- De split-feeding dieren vertoonden een tendens tot een hoger legpercentage dan de controle dieren terwijl het legpercentage van de twice-a-day-feeding dieren niet verschilde van de split-feeding en controle dieren.

- Er werden geen verschillen gevonden ten aanzien van het percentage broedeieren, breuk/kneus/wind eieren, vuile eieren, grondeieren en eigewicht.

- Er werd een tendens tot een lagere uitval bij de split-feeding dieren gevonden ten opzichte van de twice-a-day-feeding dieren, terwijl het niveau bij de controle dieren niet verschilde van de andere behandelingen.

Broederijresultaten:

- De verschillende voerstrategieën hadden geen effect op de broederijresultaten.

Broedeikwaliteit:

- Er werden geen effecten van de voerstrategieën gevonden op breuksterkte en schaaldikte.

- Er werden geen effecten van de voerstrategieën gevonden op gewicht eischaal en drogestofgehalte eischaal.

- Het albumen percentage was het laagst in de eieren van de split-feeding dieren, ten opzichte van de controle en twice-a-day-feeding dieren.

- Er was een tendens tot een hoger dooier percentage in de eieren van de split-feeding dieren ten opzichte van de twice-a-day-feeding dieren, terwijl het dooier percentage in de eieren van de controle dieren niet verschilde van de andere behandelingen.

- De albumen/dooier verhouding was het hoogst in eieren van de twice-a-day-feeding dieren, in vergelijking met de controle en split-feeding dieren.

- Er was geen effect van voerstrategie op soortelijk gewicht (specific gravity).

Bevedering:

- De verschillende voerstrategieën hadden, op het dijbeen na, geen effect op de kwaliteit van de bevedering.

Gedrag:

- De controle dieren vertoonden een tendens tot meer drinken dan de twice-a-day-feeding dieren, terwijl het drinkgedrag van de split-feeding dieren niet verschilde van de andere behandelingen.

- De tweemaal daags gevoerde dieren (twice-a-day-feeding en split-feeding) stonden meer dan de controle dieren.

- De controle dieren vertoonden een tendens tot meer zitten dan de split-feeding dieren, terwijl het percentage zitten van de twice-a-day-feeding dieren niet verschilde van de andere behandelingen.

- De twice-a-day-feeding dieren vertoonden een tendens tot meer lopen dan de controle dieren, terwijl het percentage lopen van de split-feeding dieren niet verschilde van de andere behandelingen.

- De tweemaal daags gevoerde dieren (twice-a-day-feeding en splitfeeding) foerageerden minder dan de controle dieren.

- De controle dieren vertoonden een tendens tot meer stofbaden dan de split-feeding dieren, terwijl het percentage stofbaden door de twice-a-day-feeding dieren niet verschilde van de andere behandelingen.

Gedragspatroon:

De dieren die tweemaal per dag gevoerd werden vertoonden ten opzichte van de eenmaal per dag gevoerde dieren:

- in de periode na de eerste voerbeurt minder eetgedrag en rond de tweede voerbeurt meer eetgedrag;

- vanaf de vijfde waarnemingsronde minder drinkgedrag en bij de laatste observatieronde (rond 17.00 uur) meer drinkgedrag;

- gedurende de dag meer en aan het einde van de dag minder sta-gedrag;

- tijdens de eerste helft van de dag meer en tijdens de tweede helft van de dag minder zitgedrag;

- na de eerste voerbeurt een lineaire afname van loopgedrag (alle behandelingen) en rond de tweede voerbeurt meer loopgedrag;

- foerageerden 's ochtends iets meer en 's middags minder;

- gedurende de dag meer en na de tweede voerbeurt minder comfortgedrag;

- geen verschil in stofbadgedrag tijdens de dag en rond de tweede voerbeurt minder stofbadgedrag.

- na de tweede voerbeurt minder object pikgedrag;

- nauwelijks verschillen in pikgedrag. 


\section{Conclusie}

Uit het onderzoek blijkt dat de dieren die het split-feeding programma volgden tussen 45 en 65 weken leeftijd een hogere productie en lagere uitval hadden. Daarnaast werden een lagere wateropname en lagere water/voer-verhouding gevonden bij de tweemaal daags gevoerde dieren (twice-a-day-feeding en split-feeding). Het toepassen van tweemaal daags voeren (twice-a-day-feeding en split-feeding) had nauwelijks effect op broedeikwaliteit.

Bij de tweemaal ten opzichte van eenmaal daags gevoerde dieren werd een ander gedragspatroon gedurende de dag waargenomen. De tweemaal daags gevoerde dieren kregen tweemaal daags een halve portie voer, hetgeen de belangrijkste factor was voor de verschillen in het gedragspatroon. Het was niet helemaal eenduidig maar de tweemaal daags gevoerde dieren (twice-a-day-feeding en splitfeeding) vertoonden in gemiddeld : minder drinken, meer staan, minder zitten, meer lopen en minder foerageren. 


\section{$1 \quad$ Inleiding}

Vleeskuikenouderdieren worden gehouden om zoveel mogelijk $1^{\mathrm{e}}$ soort broedeieren te produceren (Zuidhof et al., 2007). De broedeieren moeten een goede en sterke schaal hebben zodat het broedproces zonder problemen verloopt en het aantal $1^{\mathrm{e}}$ soort vleeskuikens gemaximaliseerd wordt. Door de genetische veranderingen dient echter ook het management continu aan de dieren te worden aangepast. In Noordwest Europa worden de dieren rond de 21 weken leeftijd met licht gestimuleerd om in productie te komen, waarna ze tot circa 60 weken leeftijd worden gehouden. In andere werelddelen (bijv. Noord- en Zuid-Amerika) worden de dieren vaak pas op 23 weken leeftijd gestimuleerd en worden ze vaak tot circa 65 weken leeftijd gehouden. Dit heeft onder meer vaak te maken met het feit dat in andere delen van de wereld de ondergrens voor het broedeigewicht hoger ligt (52 gram) dan in Noordwest Europa (50 gram). Wanneer dieren later gestimuleerd worden tot eieren leggen zullen ze bij de start van de productie zwaardere eieren leggen. Daarnaast hebben later gestimuleerde dieren meer kans om vetreserves op te bouwen waardoor de legpersistentie beter is en ze op latere leeftijd nog voldoende (bevruchte) eieren produceren. Naast de verbeterde reproductie is het bij langer aanhouden van ouderdieren belangrijk dat ook de schaalkwaliteit van de broedeieren goed blijft. Een verminderde schaalkwaliteit heeft een negatief effect op het aantal $1^{\mathrm{e}}$ soort broedeieren, uitkomstpercentage en kuikenkwaliteit.

De eischaalkwaliteit neemt bij vleeskuikenouderdieren aan het einde van de productieperiode meestal af. Daarom verstrekken praktijkbedrijven vanaf 40 weken leeftijd een voer met een verhoogd calciumniveau en wordt vaak extra grit verstrekt om de schaalkwaliteit te ondersteunen.

In de legsector is men de laatste jaren begonnen om split-feeding (speciaal ochtend- en middagvoer) toe te passen om de eivorming/eischaalvorming te faciliteren. Een onderzoek van de Los Mozos en Sanchez (2014) toonde aan dat het verstrekken van split-feeding bij leghennen tussen 95 en 98 weken leeftijd de schaalkwaliteit verbeterde. Het percentage breuk/windeieren was $30 \%$ lager, het eischaalgewicht was 1,3\% hoger, de eischaaldikte 1,3\% dikker en het eischaalgewicht per oppervlakte $\left(\mathrm{mg} / \mathrm{cm}^{2}\right)$ was $9 \%$ hoger. Van Krimpen et al. (2018) toonden verder aan dat het toepassen van splitfeeding bij biologische leghennen een lagere fosforuitscheiding gaf zonder negatieve effecten op eiproductie en schaalkwaliteit.

Onderzoek met split-feeding bij ouderdieren liet zien dat dit een hogere productie kan geven (van Emous et al., 2020; Trouw, 2021). In het experiment van van Emous et al. (2020) werden vleeskuikenouderdieren gevoerd volgens het split-feeding programma en vond men tussen 51 en 55 weken leeftijd een tendens tot een gemiddeld 3,2\% hoger legpercentage. In het onderzoek van Trouw (2021) vond men een significant hoger legpercentage tussen 55 en 60 weken leeftijd, wat resulteerde in meer eieren en meer kuikens. Bij een onderzoek uitgevoerd door Trouw (2021) in samenwerking met een grote Spaanse integratie bij meer dan 120.000 ouderdieren vonden zij een 1,9 hogere kuikenproductie.

Naast split-feeding is het ook mogelijk om tweemaal daags standaard foktoomvoer te verstrekken, wat in diverse studies is onderzocht. Een hogere eiproductie werd gevonden in vleeskuikenouderdieren bij twice-a-day-feeding (de Avila et al., 2003; Spradley et al., 2008; Taherkhani et al., 2010; Moradi et al., 2013; Soltanmoradi et al., 2013). Er werden echter geen effecten van verschillende voertijdstippen op productie gevonden in de studies van Cave (1981), Bootwalla et al. (1983), Samara et al. (1996) en Backhouse en Gous (2005). Het onderzoek van Londero et al. (2015) toonde aan dat dieren die om 08.00 uur ( $100 \%$ voer) of tweemaal per dag werden gevoerd een hogere productie hadden dan de dieren die om 15:00 uur (100\% voer) werden gevoerd.

Twee- of driemaal daags voer verstrekken gaf een hoger eigewicht in de studies van Cave (1981), Spradley et al. (2008) en Moradi et al. (2013). Geen effect van tijdstip van voeren op eigewicht werd echter gevonden in de studies van Samara et al. (1996), Harms (1991) en van Emous et al. (2020). 
Het verstrekken van een eenmalige portie voer in de ochtend geeft mogelijk een slechte beschikbaarheid van de nutriënten op het juiste tijdstip van de dag om in de behoefte van de ouderdieren te voorzien (Cave, 1981). Vooral het beschikbaar komen van calcium gedurende de avond en nacht is cruciaal voor de eischaalvorming (Farmer et al., 1983a,b). De vorming van de eischaal begint in de namiddag en/of vroege avond, hetgeen dus uren later is dan het verstrekken van de dagportie voer in de ochtend. Vleeskuikenouderdieren nemen, bij een eenmalige voerbeurt in de ochtend, het voer op in twee tot vier uur (Roland en Farmer, 1984; Backhouse en Gous, 2005). Uit onderzoek met vleeskuikenouderdieren bleek dat binnen vier uur na het opnemen van het voer (vanaf 7:00 uur voer verstrekken), meer dan de helft van het opgenomen calcium uit de krop verdwenen was (Farmer et al., 1983b). Uit het onderzoek van Farmer et al. (1983b) bleek verder dat vleeskuikenouderdieren in de eerste vier uur ca. $25 \%$ van het opgenomen calcium in de darmen absorberen. Deze dieren werden om 07:00 uur 's morgens gevoerd en absorbeerden na 11:00 uur vrijwel geen (slechts enkele procenten) calcium meer tot 23:00 uur 's avonds (Farmer et al., 1983b). Het benodigde calcium voor de eischaal wordt dan vanuit de calciumopslag in het bot losgemaakt, wat kan resulteren in verminderde botkwaliteit en poot- en karkasproblemen. Door vleeskuikenouderdieren later op de dag te voeren, komt het calcium meer beschikbaar op het moment van schaalvorming (Farmer et al., 1983a). Dit resulteert in een beter calciumgebruik/-benutting (Farmer et al., 1983b; Roland en Farmer, 1984) dat meestal tot uiting komt in een toename van het soortelijk gewicht van de eieren, het gewicht van de schaal en de dikte van de schaal (Backhouse and Gous, 2006). Studies van Farmer et al. (1983a), Bootwalla et al. (1983), Backhouse en Gous (2005) en Londero et al. (2015) toonden aan dat dieren die alleen 's middags voer verstrekt kregen de beste schaalkwaliteit hadden. Experimenten uitgevoerd door Brake (1985), Wilson en Keeling (1991), Samara et al. (1996) en Spradley et al. (2008) toonden echter geen effect aan van tijdstip van voeren op de kwaliteit van de eischaal.

In het onderzoek van van Emous et al. (2020) vond men geen verbetering van de eischaalkwaliteit, hetgeen wel werd gevonden in het onderzoek van Trouw (2021). In het onderzoek van Trouw (2021) vond men een hoger eischaalgewicht en een tendens tot een hoger schaalgewicht per oppervlakte eischaal $\left(\mathrm{mg} / \mathrm{cm}^{2}\right)$.

Er is nauwelijks informatie beschikbaar over het effect van verschillende voertijdstippen op broederijresultaten. Uit onderzoek van Spradley et al. (2008) bleek dat het een- of tweemaal per dag voeren geen effect had op broederijresultaten. Daarentegen vonden Soltanmoradi et al. (2013) dat twice-a-day-feeding een hogere bevruchting en uitkomsten gaf. Londero et al. (2015) vonden geen effecten van voeren om 08.00 uur (100\%), 09.00 en 15.00 uur (50/50\%) en 15.00 uur (100\%) op bevruchting en uitkomst. Wel bleek dat de dieren die om 08.00 uur de volledige voerportie verstrekt kregen een lagere embryonale sterfte ( $9,3 \%$ vs. $12,1 \%$ en $11,8 \%$ ) vertoonden en dus een hogere uitkomst hadden dan de dieren die tweemaal gevoerd werden of alleen in de middag. In het onderzoek van van Emous et al. (2020) werden geen verschillen gevonden in bevruchting en vroeg embryonale sterfte.

Het doel van het in dit rapport beschreven onderzoek is om de effecten te bestuderen van splitfeeding (speciaal ochtend- en middagvoer) en twice-a-day-feeding (twee maal daags standaard voer) ten opzichte van eenmaal per dag standaard voer verstrekken op de (re)productie, eischaalkwaliteit en gedrag van vleeskuikenouderdieren in de periode van 45 tot 65 weken leeftijd. 


\section{Materiaal en methoden}

\subsection{Dieren}

Het experiment is uitgevoerd met Ross 308 vleeskuikenouderdieren tussen 45 en 65 weken leeftijd, afkomstig van een praktijkbedrijf. De dieren zijn een week eerder aangevoerd, om ze te laten wennen aan de nieuwe omgeving. In deze periode kregen alle dieren controlevoer. Bij aanvang van het experiment ( 45 weken leeftijd) vond een selectie plaats van de aanwezige hennen, zodat er gestart werd met 30 hennen per hok. Daarbij werden te lichte, te zware, niet leggende en verwonde dieren verwijderd. De hanen (Ranger Gold) werden aangevoerd van een opfokbedrijf, waren bij aankomst 21 weken oud en moesten nog geslachtsrijp (traprijp) worden. Daarom werden de hanen in twee aparte hokken voorin beide afdelingen separaat van de hennen geplaatst. Na vier weken werd één traprijpe haan per hok bij de hennen (49 weken leeftijd) geplaatst en een week later werd een tweede haan geplaatst. Echter, dit gaf veel onrust in de hokken met het gevolg dat één van beide hanen bijna de gehele dag op het rooster of in het legnest schuilde. Daarom is na twee dagen besloten om één van beide hanen (meestal de laatst bijgeplaatste haan) weer uit de hokken te verwijderen. Daardoor is het onderzoek verder uitgevoerd met slechts één haan per hok. In totaal werd het onderzoek uitgevoerd met 720 hennen en 24 hanen.

\subsection{Huisvesting en verzorging}

De vleeskuikenouderdieren werden gehuisvest in afdeling 1 en 2 bij proefaccommodatie Carus, Bornse Weilanden 5 te Wageningen (Figuur 1). Beide afdelingen werden mechanisch geventileerd en bevatten elk twee rijen met zes hokken (totaal 24). Zie bijlage 1 voor een schematisch overzicht van de hokken.

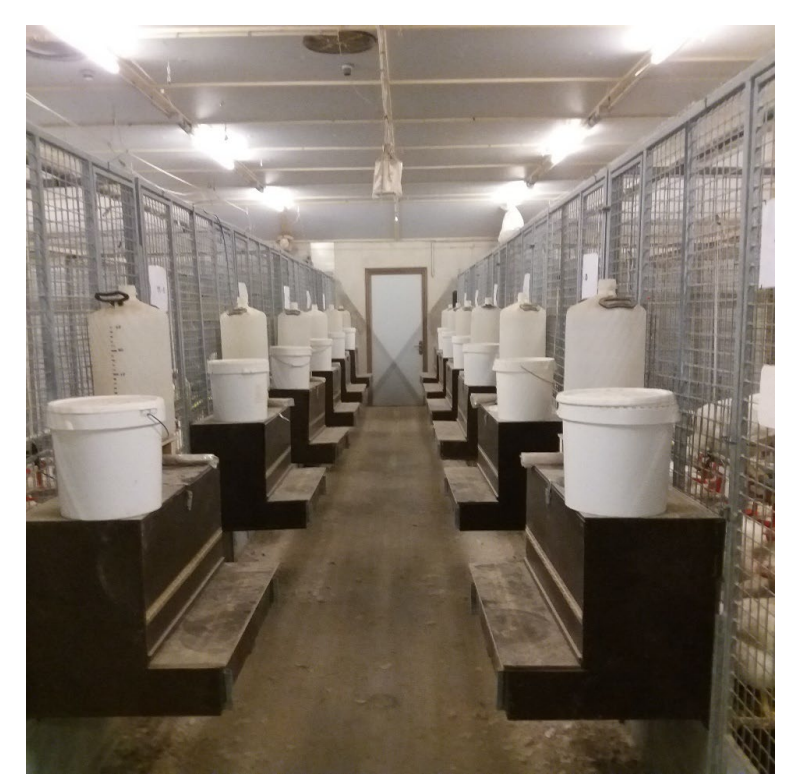

Figuur 1 Overzicht van één van de afdelingen met links en rechts de experimentele hokken.

De hokken waren elk 2,5 meter diep en 2,0 meter breed $\left(5 \mathrm{~m}^{2}\right)$. Er was een houten rooster (150 bij $100 \mathrm{~cm}$ ) geïnstalleerd met daaraan grenzend (aan de voorkant buiten het hok) een gemeenschappelijk legnest $(90 \times 40 \mathrm{~cm})$. De rest van het hok bestond uit een strooiselvloer $\left(3,5 \mathrm{~m}^{2}\right)$. Tussen de hokken was een dichte afscheiding van $40 \mathrm{~cm}$ hoog. Verder waren per hok twee kunststof zitstokken (rechthoekig met afgeronde hoeken, $4 \mathrm{~cm}$ breed en $3 \mathrm{~cm}$ hoog) met een totale lengte van 4 meter geplaatst (Figuur 2). 


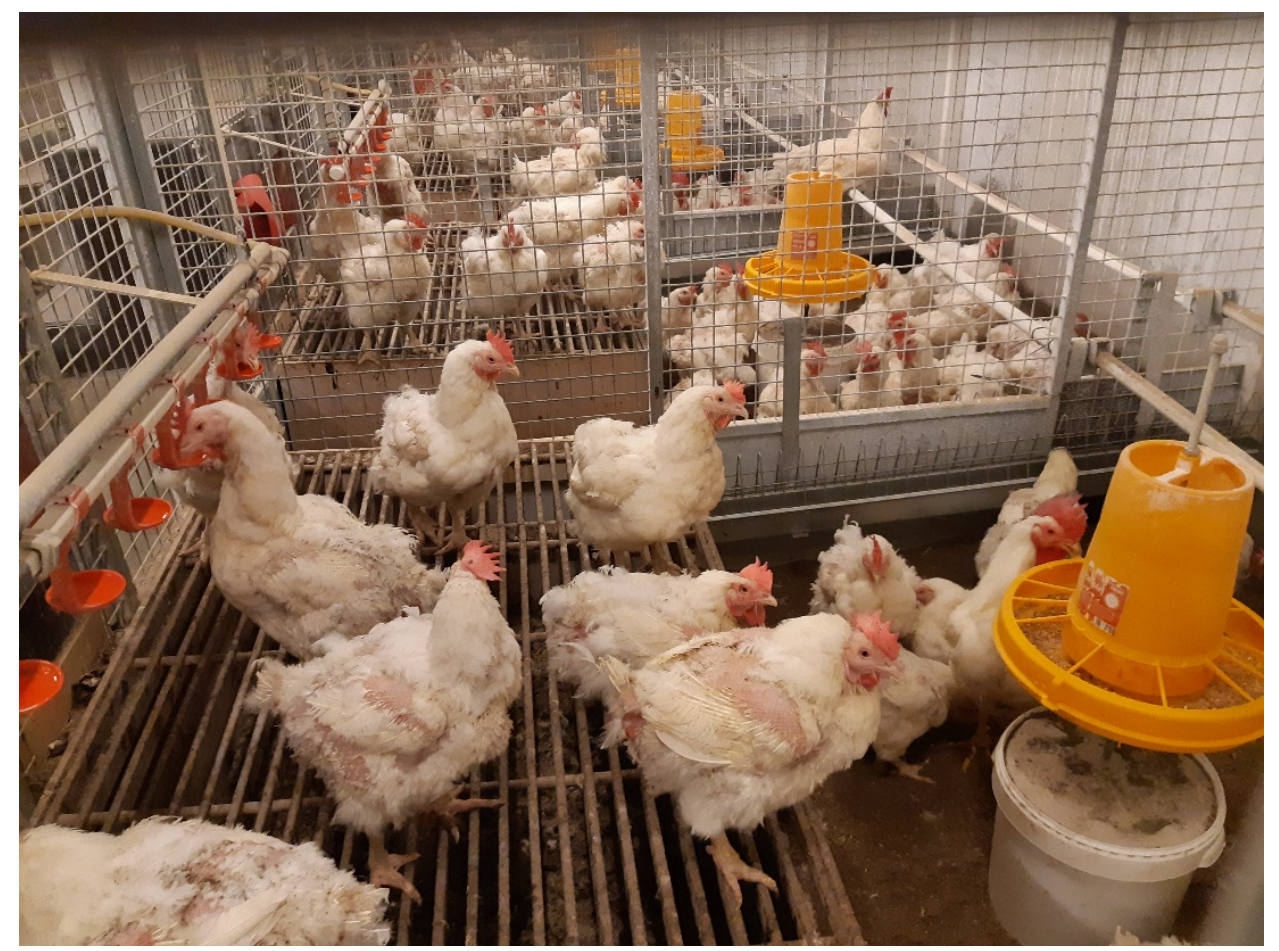

Figuur 2 Overzicht van één van de experimentele hokken met links het rooster met daarboven de drinknippellijn en daarnaast het legnest (net zichtbaar). Boven en onder (niet zichtbaar) de voergoten voor de hennen, rechts de voerbak voor de hanen en de 2 zitstokken.

Voor aanvang van het experiment werd een laagje verse houtkrullen over de vloer verspreid (1 $\mathrm{kg} / \mathrm{m}^{2}$ ). De bezetting was 6,2 dieren (hennen en hanen) per $\mathrm{m}^{2}$ waardoor er per dier $1.613 \mathrm{~cm}^{2}$ ruimte beschikbaar was. De voervoorziening voor de hennen bevond zich boven het strooisel in twee voergoten (totaal 3,7 m lengte) per hok, met een grill om te voorkomen dat hanen toegang hadden tot het voer. Hanen werden gevoerd via een aparte stabiele voerbak op minimaal $50 \mathrm{~cm}$ hoogte boven het strooisel, die niet bereikbaar was voor de hennen. De hanen kregen een speciaal hanenvoer met, ten opzichte van het foktoomvoer, lagere energie, eiwit en Ca gehalten $(2.600 \mathrm{kcal} / \mathrm{kg} \mathrm{AMEn;} \mathrm{13,0 \%}$ RE; $0,45 \%$ vert. Lys; $0,5 \%$ vert. $M+C ; 1,0 \% \mathrm{Ca} ; 0,3 \%$ oP). Water werd tijdens de lichtperiode ad libitum verstrekt via een drinknippellijn (zeven nippels per hok boven het rooster). In de namiddag (15.00 uur) kregen de dieren 2 gram per dier strooigraan op het strooisel verstrekt. De lichtperiode stond ingesteld op 14 uur licht (van 07.00 tot 21.00 uur) en de lichtsterkte was minimaal 40 lux op kophoogte. Bij het praktijkbedrijf was de verlichting ingeschakeld tussen 03.00 en 17.00 uur. Het licht ging later aan dan normaal in experimenten met ouderdieren omdat de dieren direct gevoerd moesten worden nadat het licht was aangegaan. In de praktijk wordt ook steeds meer (circa 70\%) direct gevoerd nadat het licht is aangegaan (J. Lemmens, persoonlijke communicatie). Er is naar gestreefd schaduwplekken zoveel mogelijk te beperken om grondeieren te voorkomen. Gedurende het experiment stond de streeftemperatuur ingesteld op $20^{\circ} \mathrm{C}$. Overdag was er een radio met geluid om de dieren rustiger te houden. Tijdens de proef werden de dieren tweemaal daags door de dierverzorger gecontroleerd op afwijkingen en eventuele uitval werd genoteerd. Dieren met een geconstateerde afwijking (onder andere pootproblemen en wonden) werden na overleg met de onderzoeker uit de proef gehaald.

\subsection{Experimentele opzet}

In dit experiment werden drie verschillende behandelingen (voerstrategieën) toegepast, elk met 8 herhalingen (Tabel 1). De eerste groep dieren kreeg eenmaal daags (07.30 uur) controlevoer (CON) (= standaard foktoomvoer 3). De tweede groep dieren kreeg tweemaal daags ( $50 \%$ om 07.30 uur en $50 \%$ om 16.00 uur) controlevoer (= standaard foktoomvoer 3) verstrekt (twice-a-day-feeding = TAD). De derde groep dieren kreeg tweemaal daags (07.30 en 16.00 uur) twee verschillende voersoorten verstrekt (split-feeding $\mathbf{S} \mathbf{S F}$ ). 
Het ochtendvoer bevatte meer energie, eiwit (aminozuren) en fosfor $(P)$ en minder calcium (Ca) dan het controle- en middagvoer (Bijlage 2). Het middagvoer had een lager gehalte aan energie, eiwit en $P$ en een hoger gehalte Ca ten opzichte van het controle- en ochtendvoer. Om verstrengeling van behandelingen te voorkomen werden de voeders zo geformuleerd dat de gemiddelde nutritionele waarde van het ochtend- en middagvoer vergelijkbaar was met het controlevoer. Daarnaast bestond het ochtendvoer uit $80 \%$ fijne calciumbron (krijt) en $20 \%$ grove calciumbron (kalksteentjes grof) terwijl het middagvoer bestond uit $80 \%$ grove calciumbron en $20 \%$ fijne calciumbron. Dit werd gedaan om in de ochtend de calciumvoorraad in het skelet snel aan te vullen en in de middag om de aanmaak van de eischaal gedurende de avond en nacht zoveel mogelijk te faciliteren doordat een grove calciumbron langzamer ter beschikking komt.

De dieren kregen het voer (07.30 uur) vrijwel direct nadat het licht was aangegaan (07.00 uur) verstrekt. Dit is gedaan omdat dit meer overeen komt met de huidige methode van voer verstrekken in de praktijk. De meeste bedrijven voeren 's nachts direct nadat het licht aangaat.

De dieren kregen een vooraf bepaalde voerhoeveelheid verstrekt zodat alle dieren van de verschillende behandelingen hetzelfde gewichtsschema volgden (Aviagen-EPI, 2017).

Tabel 1 Behandelingen binnen het experiment.

\begin{tabular}{lllll} 
Behandeling & Code & Voersoort & Voerfrequentie \\
A & CON & Controlevoer (standaard foktoomvoer 3) & Eenmaal per dag \\
\hline B & TAD & Twice-a-day-feeding (standaard foktoomvoer 3) & Tweemaal per dag \\
\hline C & SF & Split-feeding (speciaal ochtend- en middagvoer) & Tweemaal per dag \\
\hline
\end{tabular}

\section{$2.4 \quad$ Waarnemingen}

\subsubsection{Analyses grondstoffen en voeders}

Voor aanvang van het definitief formuleren en produceren van de experimentele voeders werden de gehaltes bepaald van de zes belangrijkste grondstoffen (tarwe, mais, zonnebloemschroot, sojaschroot, raapzaadschroot en raapzaadschilfers). Het betrof de gehaltes aan droge stof (vocht), ruw eiwit, ruw vet, ruwe celstof, ruw as, zetmeel, suikers, Ca en P. Deze gehaltes werden ook bepaald in de uiteindelijke proefvoeders.

\subsubsection{Lichaamsgewicht hennen en hanen}

Tijdens het experiment werd eenmaal per week het gemiddelde lichaamsgewicht per hok vastgesteld door een steekproef van tien hennen per hok te wegen (groepsweging). Daarnaast werd de aanwezige haan gewogen.

\subsubsection{Productieresultaten}

Gedurende het experiment werden de volgende productieresultaten verzameld: voergift, wateropname, uitval, eiproductie en -gewicht en uitsortering tweede soort eieren. De wateropname werd bepaald door de hoogte van de waterstand (dagelijks voordat het licht uitging) in het voorraadvat per hok te noteren. Het voorraadvat voor het water werd daarna aangevuld tot 11 liter zodat de dieren de gehele dag water tot hun beschikking hadden. Hieruit is de wekelijkse wateropname berekend. Dagelijks werd het aantal eieren per hok bijgehouden, waarbij onderscheid werd gemaakt tussen $1^{\mathrm{e}}$ en $2^{\mathrm{e}}$ soort broedeieren. Tweede soort eieren werden onderverdeeld in: kleinbroed $(<50 \mathrm{~g})$, dubbeldooier, breuk/kneus/wind, vuil ei of grondei. Op vrijdag werden alle broedeieren (lichter en zwaarder dan $50 \mathrm{~g}$ ) van die dag gewogen. Uitval en uitvalsoorzaak (dood, kreupel, niet leggen, wonden) werden genoteerd.

\subsubsection{Broederijresultaten}

Op 52, 59 en 65 weken leeftijd werden 50 broedeieren per hok verzameld en zeven dagen bebroed in een HatchTech Microclimer 150 om de bevruchting en embryonale sterfte na zeven dagen te bepalen. 
Tijdens de break-out werden de eieren eerst gecontroleerd op breuk/kneus en werd het aantal ingelegde eieren gecorrigeerd. De broedeieren werden open gebroken en vervolgens is beoordeeld of het ei bevrucht was en in welke fase van ontwikkeling het embryo zich bevond. De afgestorven embryo's werden geclassificeerd op vroeg (dag 1-3) en oog (dag 4-7).

\subsubsection{Broedeikwaliteit}

\section{Breuksterkte}

Op 45, 50, 55, 60 en 65 weken leeftijd werd de breuksterkte van vijftien $1^{\mathrm{e}}$ soort broedeieren per hok bepaald. De bepaling van de breuksterkte van de eischaal werd uitgevoerd met behulp van de Futura Egg Shell Tester Ver. 2 (FEST) van de Duitse fabrikant Bröring Informationstechnologie, gevestigd in Lohne (www. Broering.de). De breuksterkte werd weergegeven in Newton ( $N$ ) en gaf het moment aan waarop de eischaal, vanwege de door het apparaat uitgeoefende drukkracht op de schaal, brak. Mogelijke waarden die kunnen worden gemeten variëren van 0 tot $75 \mathrm{~N}$. Voor de breuksterktebepaling werd door middel van schouwing vastgesteld of de eischaal geen haarscheuren of andere schaalbeschadigingen vertoonde. Voor aanvang van de proef werd de FEST gekalibreerd met behulp van de door de firma Bröring verstrekte druk-gewichten van respectievelijk 500 gram en 1.000 gram.

\section{Soortelijk gewicht (specific gravity)}

Op 45, 50, 55, 60 en 65 weken leeftijd werd van vijftien $1^{\text {e }}$ soort broedeieren het soortelijk gewicht bepaald. De verzamelde eieren waren vers, maximaal 36 uur oud, en bewaard bij circa $15^{\circ} \mathrm{C}$. Voor het bepalen van het soortelijk gewicht werden 4 doorzichtige bakken met water (circa $12 \mathrm{~cm}$ vloeistofhoogte) met een oplopende dichtheid gebruikt. De bakken met water werden 24 uur voor het bepalen van het soortelijk gewicht in de meetruimte geplaatst, zodat het water bij de meting de omgevingstemperatuur had. Vervolgens werd een hoeveelheid keukenzout $(\mathrm{NaCl})$ toegevoegd, zodanig dat de dichtheid in de vier bakken achtereenvolgens 1,070, 1,075, 1,080 en 1,085 g/cm ${ }^{3}$ was (bepaald met een hydrometer).

De 15 eieren uit één hok werden bij elkaar in de bak met de laagste dichtheid $(1,070)$ gelegd. Eieren die bleven drijven werden er uit gehaald en toegekend aan "klasse 1". De eieren die op de bodem bleven liggen werden in de volgende bak (dichtheid 1,075) geplaatst. De eieren die nu bleven drijven werden er uit gehaald en toegekend aan "klasse 2". De eieren die wederom op de bodem bleven liggen werden in de volgende bak (dichtheid 1,080) geplaatst. De eieren die nu bleven drijven werden er uit gehaald en toegekend aan "klasse 3". De eieren die wederom op de bodem bleven liggen werden in de volgende bak (dichtheid 1,085) geplaatst. De eieren die nu bleven drijven zijn er uit gehaald en toegekend aan "klasse 4". De eieren die wederom op de bodem bleven liggen werden toegekend aan "klasse 5 ". Vervolgens werd het aantal eieren per klasse geteld.

Daarna zijn de eieren afgedroogd en individueel gewogen, waarna het gewicht van de individuele eieren, met de klasse, werd genoteerd.

\section{Eischaaldikte}

Op 45, 50, 55, 60 en 65 weken leeftijd werd van tien $1^{\text {e }}$ soort broedeieren de eischaaldikte gemeten. De schaaldikte van de eieren werd bepaald op drie plaatsen van het ei: de bovenkant, het midden en de onderkant (van Krimpen et al., 2018). Daarvoor werden stukjes schaal gebruikt van enkele vierkante millimeters oppervlakte, zodat de bolling van de schaal zo klein mogelijk was. Ook werd het binnenste schaalmembraan van de schaal verwijderd. De bepaling van de eischaaldikte werd uitgevoerd met de eischaaldiktemeter van Bröring, met een minimum bereik van 0,001 mm tot 3,500 $\mathrm{mm}$. De dikte wordt weergegeven in $\mathrm{mm}$ (2 decimalen). Kalibratie van de eischaaldiktemeter vond plaats door middel van het indrukken van de zero-toets die is aangebracht op het apparaat.

\section{Albumen/dooier verhouding en schaalgewicht}

Op 45, 50, 55, 60 en 65 weken leeftijd werd van tien broedeieren per hok de albumen/dooier verhouding bepaald. De eieren werden eerst vers gewogen en daarna in tien minuten hardgekookt. De hardgekookte eieren werden weer gewogen en vervolgens werden de schaal, dooier en het albumen gescheiden en gewogen. Uit deze afzonderlijke gewichten is de verhouding tussen albumen en dooier berekend ten opzichte van het gehele eigewicht en van elkaar. 
De schaalgewichten werden na 24 uur drogen bij kamertemperatuur wederom bepaald. Door het drogen was het aanwezige water in de schalen verdampt en kon ook het drogestofgehalte in de eischaal worden bepaald.

\subsubsection{Gedrag}

Op 45, 50, 55, 60 en 65 weken leeftijd werd door 2 personen gedragsonderzoek uitgevoerd (volgens de methode en ethogram naar van Emous et al., 2015). Het gedrag van de dieren werd per hok twaalf maal per waarnemingsdag vastgelegd met behulp van scan sampling (ethogram in Bijlage 3). Hierbij liepen de onderzoekers langs de hokken en werd genoteerd welk gedrag elk individueel dier op dat moment uitvoerde. De gedragingen zijn weergegeven als percentage van het totaal aantal dieren in dat hok.

\subsubsection{Bevedering}

Op 45, 50, 55, 60 en 65 weken leeftijd werd de kwaliteit van het verenpakket van vijf dieren/hok beoordeeld volgens de methode van Bilcik en Keeling (1999). Er werd gescoord op zeven onderdelen van het lichaam (nek, borst, buik, rug, vleugels, staart, dijbeen) en er werden scores gegeven tussen 0 (gaaf) tot 5 (kaal) en van 5 (geen) tot 8 (ernstig) voor verwondingen.

\subsection{Statistische analyse}

Het hok was de experimentele eenheid. De data zijn geanalyseerd met behulp van Genstat 19 (2018) software. De $P$-waarde van het behandelingseffect en de SEM (standard error of the mean) zijn per responsparameter weergegeven. Behandelingseffecten met een $P$-waarde $\leq 0,05$ worden als statistisch significant beschouwd. Een tendens tot een verschil werd beschouwd bij een $P$-waarde 0,05 $\leq P<0,10$. De responsparameters lichaamsgewichten, productieresultaten, broederijresultaten en broedeikwaliteit werden geanalyseerd met behulp van ANOVA en de parameters bevedering en gedrag met behulp van REML. Het volgende model werd toegepast: $Y_{i j}=\mu+$ Blok $_{i}+$ voerstrategie $_{j}+$ Error $_{i j}$ met $Y$ als responsparameter, $\mu$ als algemeen gemiddelde, blok als effect van de twee afdelingen $(i=1,2)$, voerstrategie als effect van de voerstrategie $(j=1 \ldots 3)$ en Error als de Error term.

Het statistische model voor broederijresultaten, eischaalkwaliteit, gedrag en bevedering bevatte ook leeftijd: $Y_{i j k}=\mu+$ Blok $_{i}+$ voerstrategie $_{j}+$ leeftijd $_{k}+$ voerstrategie*leeftijd $_{j k}+$ Error $_{i j k}$ Met: $Y$ als responsparameter, $\mu$ als algemeen gemiddelde, blok als effect van de twee afdelingen $(i=1,2)$, voerstrategie als effect van de voerstrategie $(j=1 \ldots 3)$, leeftijd als effect van de leeftijd $(k=1 \ldots 5)$ en Error als de Error term. 


\section{Resultaten}

\subsection{Verloop experiment}

Het experiment is zonder verstoringen verlopen. De dieren produceerden tussen 45 en 65 weken leeftijd ver boven de norm. Van tevoren was het idee dat de relatief oude dieren mogelijk een terugval zouden krijgen door het overplaatsen van een vertrouwde naar nieuwe omgeving. De dieren werden in het donker gevangen, getransporteerd naar de proefaccommodatie en weer uit de kratten gehaald wat in totaal bijna 4 uur in beslag nam. Tijdens het experiment kregen de dieren een ander lichtschema, ander voer, tweedaags voer, etc. De dag na overplaatsten produceerden de dieren echter gewoon $75 \%$ eieren die terugviel naar $70 \%$ op de tweede dag maar daarna herstelde waardoor de dieren de eerste (voorperiode) week bijna $77 \%$ eieren ( $P G=122$ ) produceerden. In de eerste week van het experiment ging het productiegetal naar ruim 125 en in de tweede week naar ruim 127 . De conclusie is dan ook dat oudere dieren prima kunnen worden overgeplaatst zonder gevolgen op productie. In totaal werden in de experimentele periode van 20 weken 99,0 eieren per geplaatst dier geproduceerd terwijl de norm (Aviagen, 2021) 81,3 is. De gemiddelde productie per aanwezig dier was $73,7 \%$ terwijl de norm van Aviagen (2021) $61,5 \%$ is. Dit was ook goed zichtbaar in het Productie Getal (PG = leeftijd in weken + leg\% p.a.h.) welke gemiddeld 129,2 was, terwijl dit volgens de norm 117,0 moest zijn. Verder viel het op dat het PG over de gehele experimentele periode nagenoeg gelijk bleef, wat betekent dat de productie gemiddeld met 1,0\% per week daalde. Volgens de Aviagen norm (2021) zakt het productiegetal namelijk van 118,4 op 46 weken leeftijd naar 114,8 op 65 weken wat betekent dat de productie normaal met 1,2\% per week daalt. De hogere productie in het experiment is veroorzaakt door de strenge selectie van niet leggende en zwakke dieren tijdens het experiment. In praktijkstallen blijven deze dieren vaker wat langer in het koppel aanwezig. Verder gaan er in de kleine hokken waarschijnlijk minder grondeieren verloren dan in een praktijkstal.

Het percentage grondeieren was met gemiddeld 7,4\% gedurende het experiment aan de hoge kant. In voorgaande experimenten bleek dat het percentage grondeieren (tussen 3 en 4\%) altijd hoger was dan in de praktijk (tussen 0,5 en 2,0\%). Dit komt doordat in de eerste plaats de kleine hokken relatief veel rustige hoekjes hebben en in de tweede plaats doordat de hokken relatief veel onderdelen (inrichting) hebben waar de dieren rustig kunnen zitten om grondeieren te leggen. Verder is het in deze kleine hokjes gemakkelijker om grondeieren te vinden waardoor er relatief minder verloren gaan dan in praktijkstallen. Daarnaast waren de dieren in dit experiment afkomstig van een praktijkstal waar ze al 24 weken geproduceerd hadden. Deze relatief oude dieren moesten wennen aan een nieuwe omgeving wat mogelijk meer grondeieren tot gevolg had.

Opvallend was dat er een consistent verschil was in het percentage grondeieren tussen de afdelingen. In afdeling 1 en 2 werden respectievelijk gemiddeld 4,5 en 10,2\% van de eieren op de grond aangetroffen. Dit heeft mogelijk te maken met het verschil van oorsprong van de dieren bij het praktijkbedrijf. De dieren werden 's avonds bij het praktijkbedrijf in het donker gevangen en in afdeling 2 werden relatief meer dieren geplaatst die in de praktijkstal op de grond zaten. In de regel leggen dieren die 's nachts niet op het rooster gaan zitten meer grondeieren dan dieren die 's nachts wel op het rooster zitten. Na controle bleken er in afdeling 2 meer dieren $s^{\prime}$ avonds op het strooisel te zitten en is besloten om een aantal avonden de dieren in het donker op het rooster te plaatsen. Dit is drie avonden gedaan maar het aantal dieren op het strooisel nam niet af. Mogelijk dat de dieren al te oud waren om hun gedrag aan te passen en werkt het plaatsen op het rooster alleen bij jongere dieren.

Tijdens het omhoog plaatsen van de dieren in de avond is het aantal dieren op de grond per hok genoteerd en vergeleken met het aantal grondeieren in dezelfde periode (Figuur 3). Uit de grafiek blijkt dat er een redelijk sterke correlatie $\left(R^{2}=0,47\right)$ is tussen het aantal dieren op de grond en het percentage grondeieren. 


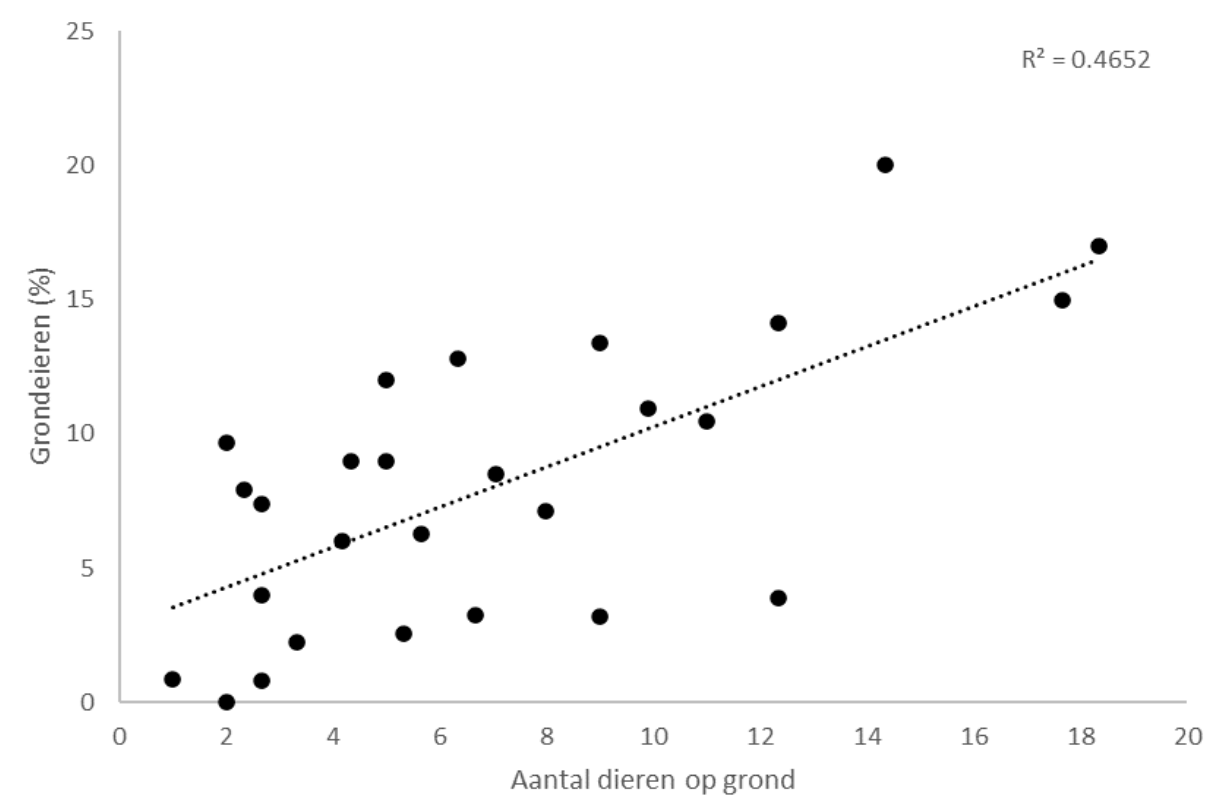

Figuur 3 Correlatie tussen het aantal dieren dat in het donker op de grond zat en het percentage grondeieren.

Doordat de strooisellaag flink dik werd en de kwaliteit afnam is op 54 weken leeftijd het strooisel verwijderd en vervangen door nieuw (wit) strooisel. Dit wordt in de praktijk ook wel toegepast om het aantal grondeieren te verminderen. Uit figuur 4 blijkt dat na het verwijderen van het strooisel, het percentage grondeieren meer dan halveerde (van gemiddeld 8,2 naar 3,5\%). Na vier weken was het percentage grondeieren echter weer opgelopen naar ruim $7 \%$ en na acht weken was het weer op het oorspronkelijke niveau.

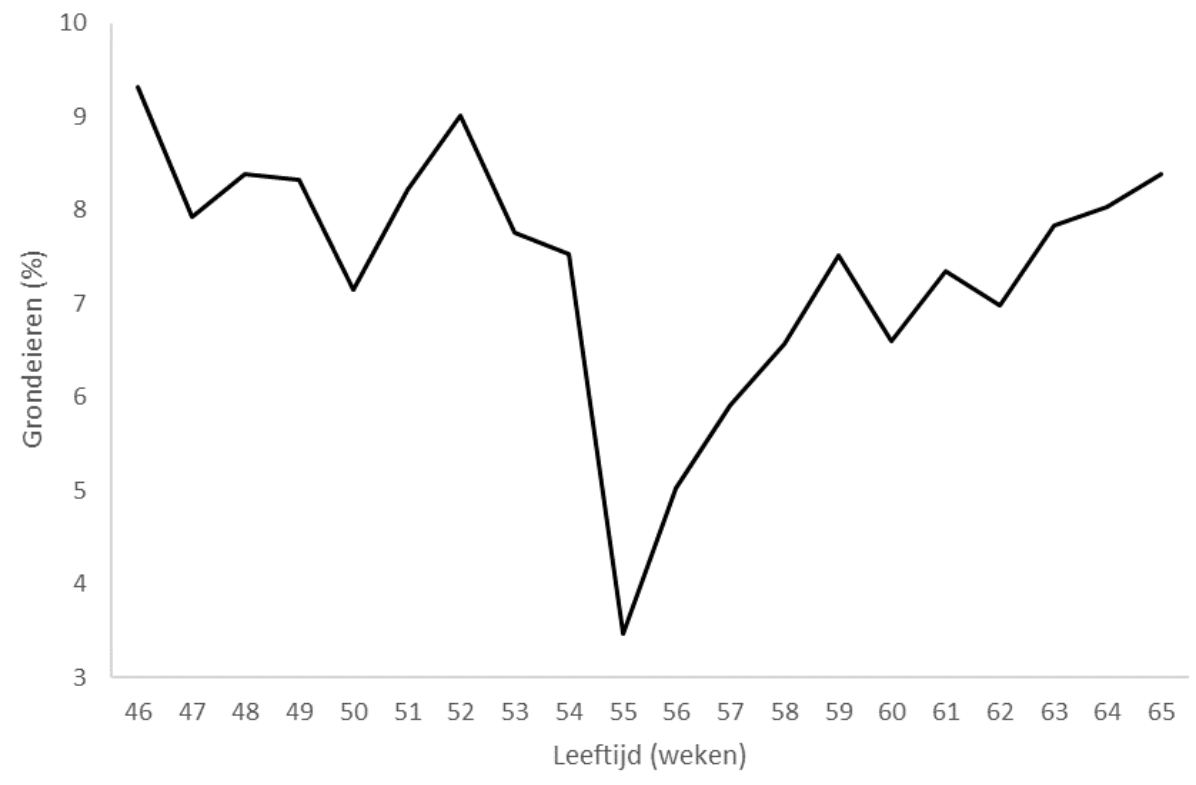

Figuur 4 Ontwikkeling van het gemiddelde percentage grondeieren.

De uitval was met 0,4\% per week (totaal 7,9\% in 20 weken) tweemaal zo hoog als in de praktijk $(0,2 \%)$. Deze hoge uitval kwam doordat de uitval bij het praktijkbedrijf ook al aan de hoge kant was. Een klein gedeelte van de dieren (21\%) werd daadwerkelijk dood gevonden. Het resterende gedeelte van de uitval (79\%) werd veroorzaakt door selectie van niet leggende (38\%), kreupele $(23 \%)$ en verwonde $(18 \%)$ dieren. De verwonde dieren waren vooral verwond aan de flanken, mogelijk veroorzaakt door de hanen.

Doordat er geen volwassen seksueel actieve hanen beschikbaar waren op het praktijkbedrijf moesten jonge hanen (Gold hanen van 21 weken leeftijd) van een opfokbedrijf betrokken worden. 
Deze hanen werden in de proefaccommodatie gedurende enkele weken in separate hokken gehouden en op volwassen gewicht (minimaal $4 \mathrm{~kg}$ ) gebracht. Voor het onderzoek waren ook waarnemingen (bevruchting en vroege embryonale sterfte) aan de broedeieren gepland. Na vier weken werd daarom één traprijpe haan per hok geplaatst en de week er na werd de tweede haan geplaatst. Echter dit gaf veel onrust in de hokken, met als gevolg dat een van beide hanen bijna de gehele dag op het rooster of in het legnest schuilde. Daarom is na twee dagen besloten om één van beide hanen (meestal de laatst bijgeplaatste haan) weer uit de hokken te verwijderen. Dit betekende dat vanaf 49 weken leeftijd maar één haan per hok $(3,4 \%)$ aanwezig was, die verantwoordelijk was voor de bevruchting van gemiddeld 29 ouderdieren.

Heel opvallend was dat in de periode dat er geen hanen tussen de hennen zaten (44 tot 49 weken leeftijd), spontaan hurkgedrag bij de hennen werd waargenomen tijdens het betreden van de hokken. Hurkgedrag hoort bij het normale vrijwillige paargedrag en wordt in het begin van de leg regelmatig waargenomen om daarna af te nemen. Normaal gesproken wordt dit gedrag na 30 weken leeftijd in praktijkstallen, maar ook in kleine hokken, nauwelijks of niet waargenomen. Dit spontaan hurkgedrag tijdens het experiment was een duidelijke aanwijzing dat de hennen wilden paren omdat ze al een tijd niet meer gepaard hadden. Later in de periode, bij aanwezigheid van de hanen, werd ook regelmatig hurkgedrag geobserveerd. Overal onderbouwd deze observatie dat de hennen een erg belangrijke rol spelen bij de voortplanting wat door Fontana et al. (1992) al eerder beschreven is. Deze onderzoekers ontdekten tijdens een experiment dat bij oudere dieren, 4,1\% van de hennen verantwoordelijk was voor $43,2 \%$ van de onbevruchte eieren. Dit kwam doordat deze hennen het contact met de hanen vermeden en dus niet meer paarden.

De gemiddelde (echte) bevruchting over alle hokken was respectievelijk 94,4, 96,0 en 93,2\% op 52, 59 en 65 weken leeftijd (Tabel 8). Opgemerkt wordt dat in onderzoek gebruik gemaakt wordt van echte bevruchting, ten opzichte van de praktijk bevruchting waar het percentage overgelegde eieren wordt gebruikt als maat voor bevruchting. In de praktijk worden naast de onbevruchte broedeieren ook de eieren uitgesorteerd die wel bevrucht waren maar waarbij de embryo vroegtijdig is afgestorven. Het is niet eenvoudig om de echte bevruchting om te rekenen naar de praktijk bevruchting (overleg) omdat het verschil ook afhankelijk is van leeftijd. Bij het ouder worden van de dieren neemt het percentage afgestorven embryo's namelijk toe. De inschatting is dat het verschil ongeveer 4 tot $5 \%$ was, waardoor het gemiddelde overleg \% (of praktijk bevruchting \%) in het huidige onderzoek ongeveer $90 \%$ was. Dit was met slechts 1 haan per hok opvallend hoog, wat mogelijk te verklaren is door de volgende oorzaken:

1. Kleine hokken: Uit voorgaand onderzoek is gebleken dat kleinere proefhokken een hogere bevruchting geven dan praktijkstallen. Dit komt hoogstwaarschijnlijk doordat de hennen veel minder mogelijkheden hebben om de hanen te ontwijken;

2. Kleine groepen dieren: In kleinere groepen dieren herkennen de dieren elkaar waardoor de rangorde (hiërarchie) duidelijk is en er weinig tot geen agressieve interactie is.

3. Slechts 1 haan per hok: Uit onderzoek is gebleken dat dezelfde haan in een kleine groep veel meer 'waltzen' (baltsgedrag) vertoont dan diezelfde haan in een grotere stal (Mols, 1978). Er is geen concurrerende haan aanwezig waardoor er geen hiërarchie gevechten en agressie onderling tussen de hanen is en de haan zich volledig kan focussen op de hennen.

4. Leeftijd hanen: De gebruikte hanen in het onderzoek waren jonge traprijpe hanen (23 weken leeftijd) die mogelijk beter in conditie bleven en actiever waren. Hanen die van dezelfde leeftijd zijn als de hennen paren bij het ouder worden minder, paringen zijn minder succesvol, produceren lagere volumes sperma met slechtere kwaliteit en de testikels worden kleiner (Duncan et al., 1990; Cassonovas, 2000, 2002; Barna et al., 2007; Sarabia Fragoso et al., 2013).

5. Lagere bezetting: In de experimentele hokken was de bezetting lager $\left(6,2 \mathrm{dieren} / \mathrm{m}^{2}\right)$ dan wat gebruikelijk is in de praktijk (ca. 7,5 dieren $/ \mathrm{m}^{2}$ ). Uit onderzoek van de Jong et al. (2011) is bekend dat een lagere bezetting een beter paargedrag (meer vrijwillige en gelukte paringen) en een hogere bevruchting en uitkomst van de eieren geeft.

De hanen zijn wekelijks gewogen en het gewichtsverloop van de verschillende hanen verschilde enorm (Figuur 5). Dit was met name opmerkelijk omdat de hanen hetzelfde voer en dezelfde voerhoeveelheid vertrekt kregen. Mogelijk dat er een verschil is geweest in meevreten van de hennen bij individuele hanen waardoor deze minder voer konden opnemen. 


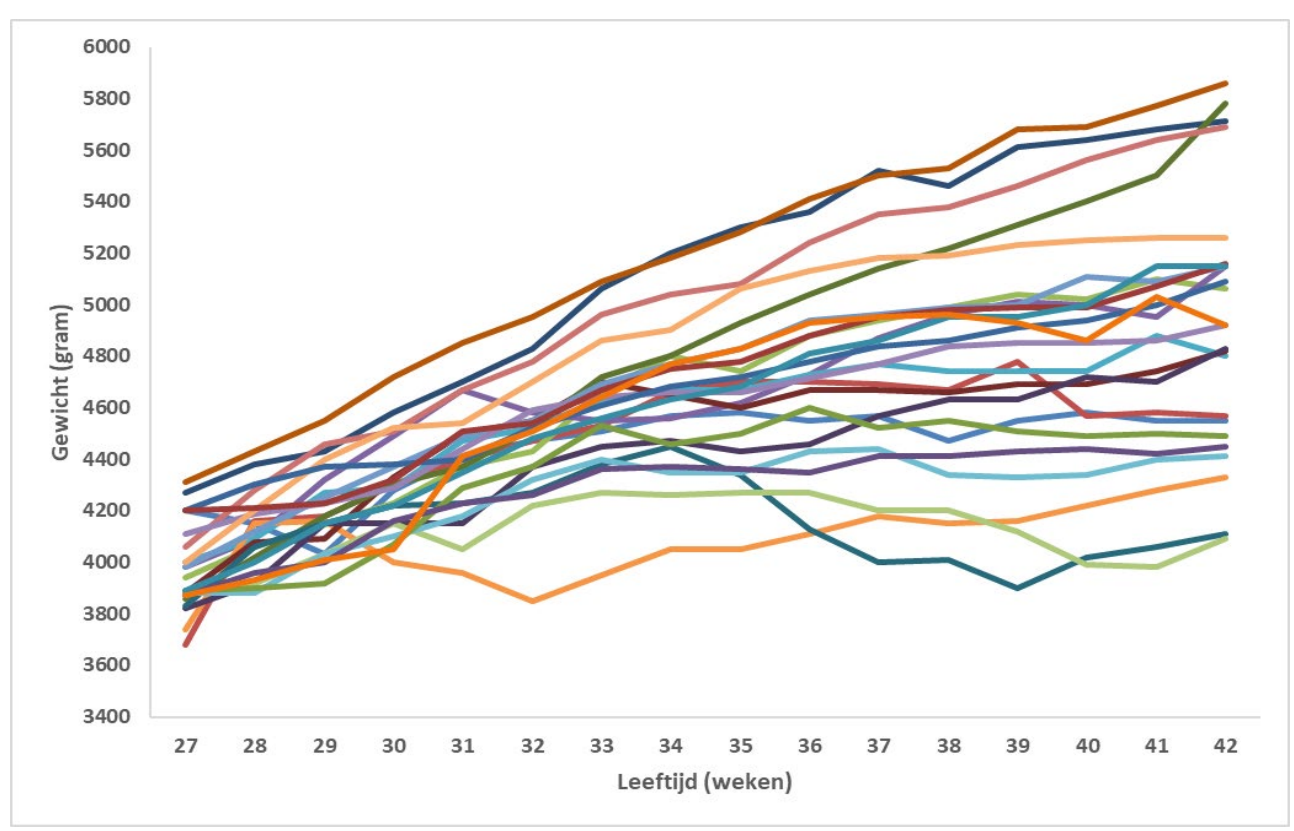

Figuur 5 Ontwikkeling van het lichaamsgewicht van individuele hanen.

Voor een verder analyse zijn de individuele hanen verdeeld in verschillende gewichtsklassen waarbij het eindgewicht op 42 weken leeftijd (hanen leeftijd en 65 weken leeftijd hennen) leidend was. De hanen werden verdeeld over zes klassen ( 3 tot 5 hanen per klasse) tussen 4.000 en 5.800 gram met een interval van 300 gram: 4.000-4.300, 4.300-4.600, 4.600-4.900, 4.900-5.200, 5.200-5.500 en 5.500-5.800 gram (Tabel 2). De gemiddelde groei per week verschilde, voor de laagste ten opzichte van de zwaarste hanen, met maar liefst 79 gram (24 t.o.v. 103 gram) terwijl er opmerkelijk, geen verschil in echte bevruchting was tussen de verschillende gewichtsklassen.

Tabel 2 Effect van verschillende eindgewichtsklassen hanen op echte bevruchting.

\begin{tabular}{|c|c|c|c|c|}
\hline Gewichtsklasse & Begingewicht (g) & Eindgewicht (g) & Groei/week (g) & Echte bevruchting ( $\%$ ) \\
\hline $4.300-4.600$ & 3.904 & 4.494 & 39 & 94.0 \\
\hline $4.600-4.900$ & 3.953 & 4.843 & 59 & 93.9 \\
\hline $4.900-5.200$ & 4.009 & 5.097 & 73 & 95.0 \\
\hline
\end{tabular}

Bovenstaande individuele hanen zijn daarnaast verdeeld over vijf verschillende gewichtsontwikkeling patronen: hard stijgend, medium stijgend, licht stijgend, eerst stijgend + daarna stabiliserend en eerst stijgend + daarna dalend (Figuur 6). 


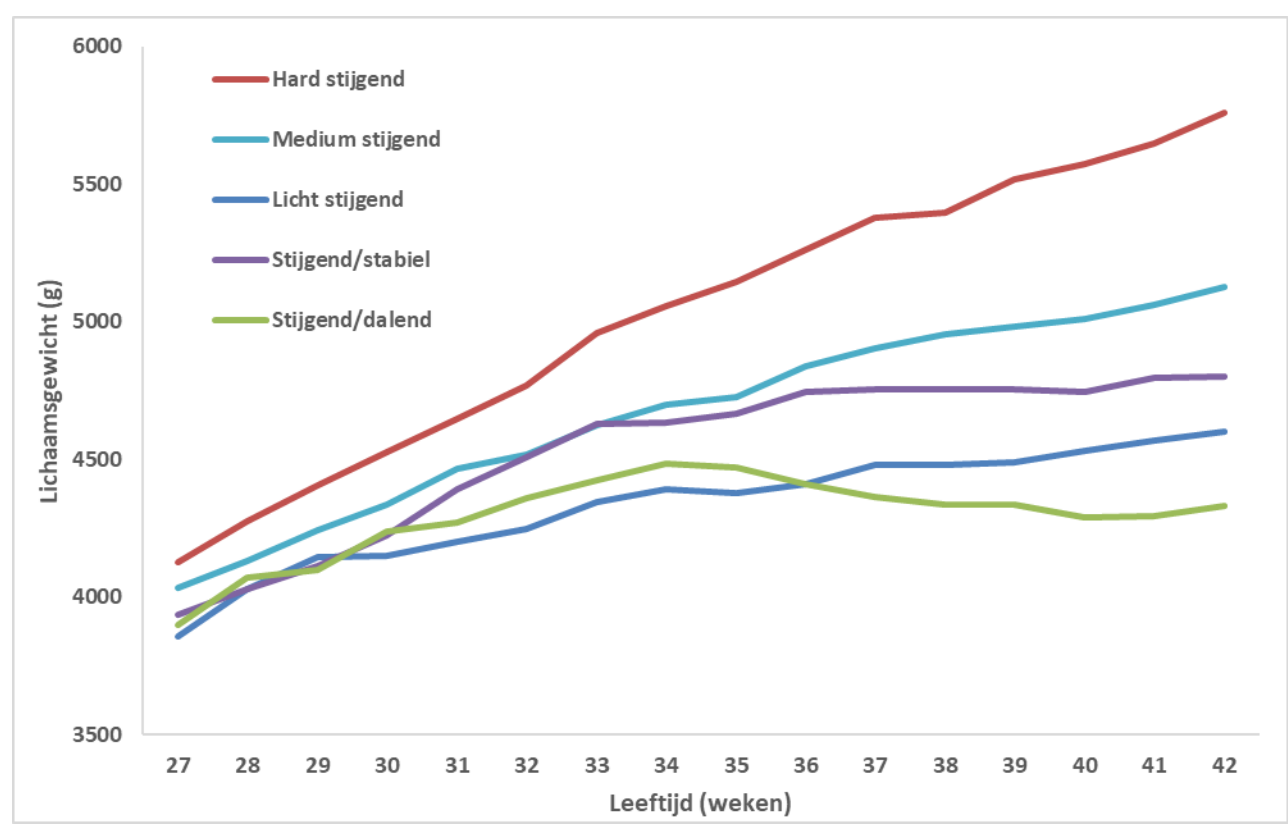

Figuur 6 Ontwikkeling van het lichaamsgewicht van de hanen verdeeld naar verschillende gewichtsontwikkeling patronen.

Uit Tabel 3 blijkt dat de hanen die het hardst groeiden ook al wat zwaarder waren aan het begin van de productieperiode. Daarnaast valt het op dat de hanen die het medium gewichtsontwikkeling volgde, numeriek de hoogste echte bevruchting gaf. Verder is het opvallend dat de hanen die eerst groeide en naderhand gewicht verloren een prima bevruchting gaven.

Tabel 3 Effect van verschillende gewichtsontwikkeling patronen hanen op echte bevruchting.

\begin{tabular}{lcccc}
$\begin{array}{l}\text { Gewichtsontwik- } \\
\text { keling patroon }\end{array}$ & Begingewicht $(\mathrm{g})$ & Eindgewicht $(\mathrm{g})$ & Groei/week $(\mathrm{g})$ & $\begin{array}{c}\text { Echte bevruchting }(\%) \\
\text { Hard stijgend }\end{array}$ \\
\hline Medium stijgend & 4.125 & 5.760 & 109 & 93,1 \\
\hline Licht stijgend & 4.032 & 5.127 & 73 & 95,9 \\
\hline Stijgend/stabiel & 3.858 & 4.603 & 50 & 93,4 \\
\hline Stijgend/dalend & 3.938 & 4.803 & 58 & 94,3 \\
\hline
\end{tabular}

\subsection{Analyse voeders}

Het geanalyseerde drogestofgehalte van de voeders was gemiddeld $1,1 \%$ lager dan de berekende gehalten (Tabel 4). Het geanalyseerde ruw eiwitgehalte van het controle, ochtend- en middagvoer was goed vergelijkbaar met de berekende gehalten. Het geanalyseerde ruw vetgehalte was voor alle drie de voeders hoger (gemiddeld 9,4\%) dan de berekende gehalten. Doordat de geanalyseerde gehalten voor alle voeders hoger waren, bleef het gewenste contrast tussen de voeders aanwezig. Het geanalyseerde ruwe celstofgehalte lag voor alle voeders ook hoger dan de berekende gehalten. Het geanalyseerde ruw asgehalte lag daarentegen lager voor alle voeders ten opzichte van de berekende gehalten. Het geanalyseerde zetmeelgehalte lag goed in lijn met de berekende gehalten.

Het geanalyseerde calciumgehalte was voor het controle en middagvoer respectievelijk 5,4 en 4,6\% lager ten opzichte van de berekende gehalten. Het geanalyseerde calciumgehalte van het ochtendvoer was 3,8\% hoger ten opzichte van het berekende gehalte. Het geanalyseerde fosforgehalte was voor het controle, ochtend- en middagvoer respectievelijk 7,4, 0,7 en 6,6\% lager ten opzichte van de berekende gehalten. Doordat de geanalyseerde gehalten in alle voeders hoger waren, bleef het gewenste contrast tussen de voeders aanwezig. 


\begin{tabular}{|c|c|c|c|c|c|c|}
\hline \multirow[t]{2}{*}{ Nutriënt } & \multicolumn{2}{|c|}{ Controle voer } & \multicolumn{2}{|c|}{ Ochtendvoer } & \multicolumn{2}{|c|}{ Middagvoer } \\
\hline & Berekend & Analyse & Berekend & Analyse & Berekend & Analyse \\
\hline Droge stof & 889,5 & 879,0 & 887,0 & 878,0 & 892,1 & 883,0 \\
\hline Ruw eiwit & 139,0 & 142,0 & 146,3 & 144,0 & 131,3 & 130,0 \\
\hline Ruw vet & 48,0 & 52,0 & 48,7 & 54,0 & 45,0 & 49,0 \\
\hline Ruwe celstof & 41,2 & 45,0 & 40,0 & 45,0 & 41,7 & 42,0 \\
\hline Ruw as & 111,3 & 98,0 & 88,4 & 86,0 & 135,1 & 125,0 \\
\hline Zetmeel & 409,0 & 400,0 & 425,6 & 396,0 & 399,6 & 397,0 \\
\hline Calcium & 33,5 & 31,7 & 24,2 & 25,1 & 43,1 & 41,1 \\
\hline Fosfor & 4,46 & 4,13 & 4,61 & 4,58 & 4,25 & 3,97 \\
\hline
\end{tabular}

\subsection{Lichaamsgewicht hennen en hanen}

Het lichaamsgewicht van de hennen en hanen was gedurende het experiment niet verschillend tussen de behandelingen (Tabel 5). Opgemerkt wordt dat de werkelijke leeftijd van de hanen 23 weken jonger is omdat het bijplaats hanen waren.

Tabel 5 Lichaamsgewichten $(g)$ hennen en hanen.

\begin{tabular}{|c|c|c|c|c|c|c|c|c|c|}
\hline \multirow{2}{*}{$\begin{array}{l}\text { Voer- } \\
\text { strategie }^{1}\end{array}$} & \multicolumn{5}{|c|}{ Hennen } & \multicolumn{4}{|c|}{ Hanen $^{2}$} \\
\hline & 45 wk & 50 wk & 55 wk & 60 wk & 65 wk & 50 wk & 55 wk & 60 wk & 65 wk \\
\hline CON & 4.028 & 4.081 & 4.062 & 4.188 & 4.268 & 4.000 & 4.498 & 4.818 & 5.038 \\
\hline TAD & 4.015 & 4.032 & 4.122 & 4.133 & 4.213 & 3.882 & 4.479 & 4.849 & 5.011 \\
\hline SF & 4.028 & 4.067 & 4.032 & 4.076 & 4.218 & 3.911 & 4.480 & 4.690 & 4.745 \\
\hline SEM & 34,3 & 26,2 & 30,2 & 45,0 & 35,6 & 79,8 & 84,0 & 146,5 & 184,1 \\
\hline$P$-waarde & 0,95 & 0,41 & 0,12 & 0,24 & 0,49 & 0,56 & 0,99 & 0,72 & 0,48 \\
\hline
\end{tabular}

${ }^{1} \mathrm{CON}=$ controle voer eenmaal/dag, TAD = twice-a-day-feeding: controle voer tweemaal/dag, $\mathrm{SF}=$ split-feeding tweemaal/dag.

${ }^{2}$ Werkelijke leeftijd van de hanen is respectievelijk 26, 31, 36 en 41 weken. 


\subsection{Productieresultaten}

Doordat er geen verschillen ontstonden in diergewicht was de voergift voor de verschillende voerstrategieën hetzelfde (Tabel 6).

Tabel 6 Voergift hennen per behandeling en gemiddelde voergift hanen (g/dier/dag).

\begin{tabular}{|c|c|c|c|c|}
\hline \multirow[t]{2}{*}{ Leeftijd } & \multicolumn{3}{|c|}{ Hennen } & \multirow[t]{2}{*}{ Hanen } \\
\hline & $\mathrm{CON}^{1}$ & TAD & SF & \\
\hline 46 & 163 & 163 & 163 & 120 \\
\hline 47 & 163 & 163 & 163 & 130 \\
\hline 48 & 163 & 163 & 163 & 150 \\
\hline 49 & 162 & 162 & 162 & 175 \\
\hline 50 & 161 & 161 & 161 & 175 \\
\hline 51 & 161 & 161 & 161 & 175 \\
\hline 52 & 161 & 161 & 161 & 175 \\
\hline 53 & 162 & 162 & 162 & 175 \\
\hline 54 & 161 & 161 & 161 & 175 \\
\hline 55 & 162 & 162 & 162 & 175 \\
\hline 56 & 162 & 162 & 162 & 175 \\
\hline 57 & 163 & 163 & 163 & 175 \\
\hline 58 & 163 & 163 & 163 & 175 \\
\hline 59 & 164 & 164 & 164 & 175 \\
\hline 60 & 163 & 163 & 163 & 175 \\
\hline 61 & 163 & 163 & 163 & 175 \\
\hline 62 & 163 & 163 & 163 & 175 \\
\hline 63 & 163 & 163 & 163 & 175 \\
\hline 64 & 164 & 164 & 164 & 175 \\
\hline 65 & 165 & 165 & 165 & 175 \\
\hline Gemiddeld & 162,6 & 162,6 & 162,6 & 168,8 \\
\hline
\end{tabular}

Er was een tendens tot een lagere wateropname $(P=0,055)$ en water/voer-verhouding $(P=0,054)$ voor de dieren die tweemaal daags gevoerd werden (twice-a-day-feeding en split-feeding) (Tabel 7).

Tabel 7 Effecten van de verschillende voerstrategieën op wateropname en water/voerverhouding.

\begin{tabular}{lcr} 
Voerstrategie $^{1}$ & Water opname $(\mathrm{ml} / \mathrm{d} / \mathrm{d})$ & Water/voer-verhouding \\
CON & $278,6^{\mathrm{x}}$ & $1,71^{\mathrm{x}}$ \\
\hline TAD & $265,3^{y}$ & $1,63^{y}$ \\
\hline SF & $265,0^{y}$ & $1,63^{y}$ \\
\hline SEM & 4,21 & 0,026 \\
\hline$P$-waarde & 0,055 & 0,054 \\
\hline
\end{tabular}

$x, y$ Verschillende letters geven een tendens tot een verschil aan $(0,05 \leq P<0,10)$.

${ }^{1} \mathrm{CON}=$ controle voer eenmaal/dag, $\mathrm{TAD}=$ twice-a-day-feeding: controle voer tweemaal/dag, $\mathrm{SF}=$ split-feeding tweemaal/dag.

De split-feeding dieren vertoonden een tendens tot een hoger legpercentage dan de controle dieren terwijl het legpercentage van de twice-a-day-feeding dieren niet verschilde van de split-feeding en controle dieren $(P=0,063$; Tabel 8$)$. Er werden geen verschillen gevonden ten aanzien van het percentage broedeieren, breuk/kneus/wind eieren, vuile eieren, grondeieren en eigewicht. Wel werd er een tendens $(P=0,098)$ tot een lagere uitval $(5,4$ vs. $10,4 \%)$ bij de split-feeding dieren gevonden ten opzichte van de twice-a-day-feeding dieren. De uitval bij de controle dieren verschilde niet van de beide andere behandelingen. 
Tabel 8

Effecten van de verschillende voerstrategieën op productieresultaten.

\begin{tabular}{|c|c|c|c|c|c|c|c|}
\hline $\begin{array}{l}\text { Voer- } \\
\text { strategie }{ }^{1}\end{array}$ & $\operatorname{Leg}(\%)$ & $\mathrm{BE}(\%)^{2}$ & BKW $(\%)^{3}$ & Vuil $(\%)^{4}$ & $\begin{array}{l}\text { Grond } \\
(\%)^{5}\end{array}$ & $\begin{array}{c}\text { Eigewicht } \\
\text { (g) }\end{array}$ & Uitval ( $\%)$ \\
\hline CON & $72,4^{y}$ & 63,8 & 1,58 & 4,03 & 6,09 & 66,3 & $7,6^{x y}$ \\
\hline TAD & $74,2^{x y}$ & 63,1 & 1,30 & 4,61 & 8,92 & 66,8 & $10,4^{x}$ \\
\hline SF & $74,5^{x}$ & 64,8 & 1,51 & 4,21 & 7,08 & 66,2 & $5,4^{y}$ \\
\hline SEM & 0,64 & 1,51 & 0,142 & 0,553 & 1,894 & 0,23 & 1,54 \\
\hline$P$-waarde & 0,063 & 0,73 & 0,39 & 0,75 & 0,57 & 0,23 & 0,098 \\
\hline
\end{tabular}

$x, y$ Verschillende letters geven een tendens tot een verschil aan $(0,05 \leq P<0,10)$.

${ }^{1} \mathrm{CON}=$ controle voer eenmaal/dag, $\mathrm{TAD}=$ twice-a-day-feeding: controle voer tweemaal/dag, $\mathrm{SF}=$ split-feeding tweemaal/dag.

${ }^{2} \mathrm{BE}(\%)=$ percentage broedeieren.

${ }^{3} \mathrm{BKW}(\%)=$ percentage breuk, kneus en wind eieren.

${ }^{4}$ Vuil $(\%)=$ percentage vuilschalige nesteieren.

${ }^{5}$ Grond $(\%)=$ percentage grondeieren.

\subsection{Broederijresultaten}

De verschillende voerstrategieën hadden geen effect op de broederijresultaten (Tabel 9). Wel was er een leeftijdseffect $(P<0,001)$ op embryonale sterfte, waarbij die toenam bij het ouder worden van de hennen.

Tabel 9 Effecten van de verschillende voerstrategieën en leeftijden op broederijresultaten.

\begin{tabular}{|c|c|c|}
\hline Item $^{1}$ & Bevruchting ( $\%)$ & Embryonale sterfte ( $\%)$ \\
\hline \multicolumn{3}{|l|}{ Voerstrategie $^{1}$} \\
\hline CON & 94,3 & 1,3 \\
\hline TAD & 93,8 & 1,0 \\
\hline SF & 95,5 & 1,4 \\
\hline SEM & 1,08 & 0,31 \\
\hline \multicolumn{3}{|l|}{ Leeftijd } \\
\hline $52 \mathrm{wk}$ & 94,4 & $0,4^{\mathrm{b}}$ \\
\hline $59 \mathrm{wk}$ & 96,0 & $1,0^{\mathrm{ab}}$ \\
\hline $65 \mathrm{wk}$ & 93,2 & $2,3^{a}$ \\
\hline SEM & 1,08 & 0,31 \\
\hline \multicolumn{3}{|l|}{$P$-waarde } \\
\hline Voerstrategie & 0,52 & 0,65 \\
\hline Leeftijd & 0,18 & $<0,001$ \\
\hline Voerstr*Leeftijd & 0,69 & 0,091 \\
\hline
\end{tabular}




\subsection{Broedeikwaliteit}

Er werden geen effecten van de voerstrategieën gevonden op eigewicht, breuksterkte en eischaaldikte (Tabel 10). Wel waren er effecten van leeftijd, waarbij het eigewicht toenam bij toenemende leeftijd terwijl de breuksterkte af nam bij toenemende leeftijd.

Tabel 10 Effecten van de verschillende voerstrategieën en leeftijden op eigewicht ( $g$ ), breuksterkte en eischaaldikte.

\begin{tabular}{|c|c|c|c|}
\hline Item $^{1}$ & Eigewicht (g) & Breuksterkte (N) & Eischaaldikte $(\mathrm{mm})$ \\
\hline \multicolumn{4}{|l|}{ Voerstrategie $^{1}$} \\
\hline CON & 66,6 & 39,2 & 0,339 \\
\hline TAD & 66,5 & 39,4 & 0,338 \\
\hline SF & 65,9 & 39,9 & 0,342 \\
\hline SEM & 0,27 & 0,42 & 0,0019 \\
\hline \multicolumn{4}{|l|}{ Leeftijd } \\
\hline $45 w k$ & $64,6^{d}$ & $39,9^{b}$ & 0,339 \\
\hline $50 w k$ & $65,7^{c}$ & $41,2^{a}$ & 0,342 \\
\hline 55 wk & $65,9^{c}$ & $40,1^{\mathrm{ab}}$ & 0,339 \\
\hline $60 w k$ & $67,3^{b}$ & $38,7^{b c}$ & 0,342 \\
\hline 65 wk & $68,0^{a}$ & $37,6^{c}$ & 0,338 \\
\hline SEM & 0,19 & 0,43 & 0,0015 \\
\hline \multicolumn{4}{|l|}{$P$-waarde } \\
\hline Voerstrategie & 0,15 & 0,47 & 0,31 \\
\hline Leeftijd & $<0,001$ & $<0,001$ & 0,25 \\
\hline Voerstr*Leeftijd & 0,030 & 0,56 & 0,67 \\
\hline
\end{tabular}

$\mathrm{a}, \mathrm{b}, \mathrm{c}, \mathrm{d}$ Verschillende letters geven een significant verschil aan $(P \leq 0,05)$.

${ }^{1} \mathrm{CON}=$ controle voer eenmaal/dag, $\mathrm{TAD}=$ twice-a-day-feeding: controle voer tweemaal/dag, $\mathrm{SF}=$ split-feeding tweemaal/dag.

Het eigewicht van de twice-a-day-feeding dieren was hoger dan van de split-feeding dieren, terwijl het eigewicht van de controle dieren niet verschilde van die van de andere behandelingen (Tabel 11). Opgemerkt wordt dat het hier bepaalde eigewicht afwijkt van de eigewichten in Tabel 8 en 10 doordat het eigewicht in Tabel 8 iedere week is bepaald en het eigewicht in Tabel 10 van een andere steekproef eieren.

Er was geen effect van de voerstrategieën op het eischaalgewicht en het drogestofgehalte van de eischaal.

Het eigewicht nam toe in de tijd en het gewicht van de eischaal (na koken en na 24 uur) was het hoogst op 60 weken leeftijd. Het drogestofgehalte was vergelijkbaar tussen 45 en 60 weken leeftijd en was lager op 65 weken leeftijd. 
Tabel 11 Effecten van de verschillende voerstrategieën en leeftijden op eigewicht, gewicht eischaal en droge stofgehalte eischaal.

\begin{tabular}{|c|c|c|c|c|}
\hline Item ${ }^{1}$ & Eigewicht (g) & $\begin{array}{c}\text { Gewicht eischaal na } \\
\text { koken (g) }\end{array}$ & $\begin{array}{l}\text { Gewicht eischaal na } \\
24 \text { uur (g) }\end{array}$ & $\begin{array}{c}\text { Drogestofgehalte } \\
\text { eischaal }(\%)\end{array}$ \\
\hline \multicolumn{5}{|l|}{ Voerstrategie $^{1}$} \\
\hline CON & $66,5^{\mathrm{ab}}$ & 6,44 & 5,78 & 89,9 \\
\hline TAD & $67,0^{\mathrm{a}}$ & 6,51 & 5,85 & 89,9 \\
\hline SF & $66,0^{\mathrm{b}}$ & 6,48 & 5,82 & 89,8 \\
\hline SEM & 0,23 & 0,027 & 0,026 & 0,08 \\
\hline \multicolumn{5}{|l|}{ Leeftijd } \\
\hline $45 w k$ & $65,3^{c}$ & $6,40^{c}$ & $5,72^{c}$ & $89,4^{\mathrm{b}}$ \\
\hline $50 \mathrm{wk}$ & $66,2^{\mathrm{b}}$ & $6,50^{\mathrm{ab}}$ & $5,86^{\mathrm{ab}}$ & $90,1^{\mathrm{a}}$ \\
\hline $55 \mathrm{wk}$ & $65,9 \mathrm{bc}$ & $6,49 \mathrm{abc}$ & $5,84^{\mathrm{ab}}$ & $90,0^{\mathrm{a}}$ \\
\hline $60 \mathrm{wk}$ & $67,3^{\mathrm{ab}}$ & $6,55^{\mathrm{a}}$ & $5,90^{\mathrm{a}}$ & $90,1^{\mathrm{a}}$ \\
\hline $65 \mathrm{wk}$ & $67,9^{\mathrm{a}}$ & $6,44^{\mathrm{bc}}$ & $5,78^{\mathrm{bc}}$ & $89,8^{\mathrm{a}}$ \\
\hline SEM & 0,30 & 0,035 & 0,033 & 0,11 \\
\hline \multicolumn{5}{|l|}{$P$-waarde } \\
\hline Voerstrategie & 0,007 & 0,18 & 0,16 & 0,77 \\
\hline Leeftijd & $<0,001$ & 0,032 & 0,002 & $<0,001$ \\
\hline Voerstr*Leeftijd & 0,44 & 0,57 & 0,66 & 0,30 \\
\hline
\end{tabular}

a,b,c Verschillende letters geven een significant verschil aan $(P \leq 0,05)$

${ }^{1} \mathrm{CON}=$ controle voer eenmaal/dag, TAD = twice-a-day-feeding: controle voer tweemaal/dag, $\mathrm{SF}=$ split-feeding tweemaal/dag.

Het eigewicht na koken van de twice-a-day-feeding dieren was hoger dan van de split-feeding dieren, terwijl het eigewicht van de controle dieren niet verschilde van die van de andere behandelingen (Tabel 12). Het albumen percentage was het laagst bij de eieren van de split-feeding dieren ten opzichte van de controle en twice-a-day-feeding dieren. Er was een tendens tot een hoger dooier percentage voor de eieren van de split-feeding dieren ten opzichte van de twice-a-day-feeding dieren, terwijl het dooier percentage van de eieren van de controle dieren niet verschilde van die van de andere behandelingen. De albumen/dooier verhouding was het hoogst voor eieren van de twice-aday-feeding dieren in vergelijking met de controle en split-feeding dieren.

In het algemeen namen het eigewicht (na koken) en het dooier percentage toe bij toenemende leeftijd, terwijl het albumen percentage en de albumen/dooier verhouding bij toenemende leeftijd afnamen. 
Tabel 12 Effecten van de verschillende voerstrategieën en leeftijden op eigewicht na koken, albumen\%, dooier\% en albumen/dooier verhouding.

\begin{tabular}{|c|c|c|c|c|}
\hline Item $^{1}$ & $\begin{array}{l}\text { Eigewicht na koken } \\
\text { (g) }\end{array}$ & Albumen $\%$ & Dooier\% & $\begin{array}{l}\text { Albumen/dooier } \\
\text { verhouding }\end{array}$ \\
\hline \multicolumn{5}{|l|}{ Voerstrategie $^{1}$} \\
\hline CON & $64,9^{\mathrm{ab}}$ & $56,5^{a}$ & $33,4^{x y}$ & $1,70^{\mathrm{b}}$ \\
\hline TAD & $65,5^{a}$ & $56,7^{a}$ & $33,2^{y}$ & $1,72^{\mathrm{a}}$ \\
\hline SF & $64,4^{\mathrm{b}}$ & $56,3^{\mathrm{b}}$ & $33,5^{x}$ & $1,69^{b}$ \\
\hline SEM & 0,23 & 0,09 & 0,09 & 0,007 \\
\hline \multicolumn{5}{|l|}{ Leeftijd } \\
\hline $45 w k$ & $63,5^{c}$ & $56,5^{\mathrm{ab}}$ & $33,2^{b}$ & $1,71^{\mathrm{b}}$ \\
\hline $50 \mathrm{wk}$ & $64,4^{b}$ & $56,8^{a}$ & $33,0^{\mathrm{b}}$ & $1,73^{\mathrm{ab}}$ \\
\hline $55 \mathrm{wk}$ & $64,3^{\mathrm{bc}}$ & $56,8^{a}$ & $32,9^{b}$ & $1,74^{\mathrm{a}}$ \\
\hline $60 \mathrm{wk}$ & $65,8^{\mathrm{a}}$ & $56,1^{\mathrm{b}}$ & $33,8^{\mathrm{a}}$ & $1,67^{c}$ \\
\hline $65 \mathrm{wk}$ & $66,6^{\mathrm{a}}$ & $56,2^{\mathrm{b}}$ & $34,0^{\mathrm{a}}$ & $1,66^{c}$ \\
\hline SEM & 0,30 & 0,11 & 0,11 & 0,009 \\
\hline \multicolumn{5}{|l|}{$P$-waarde } \\
\hline Voerstrategie & 0,005 & 0,06 & 0,069 & 0,022 \\
\hline Leeftijd & $<0,001$ & $<0,001$ & $<0,001$ & $<0,001$ \\
\hline Voerstr*Leeftijd & 0,40 & 0,68 & 0,77 & 0,81 \\
\hline
\end{tabular}

$\mathrm{a}, \mathrm{b}, \mathrm{c}$ Verschillende letters geven een significant verschil aan $(P \leq 0,05)$.

$x, y$ Verschillende letters geven een tendens tot verschil aan $(0,05 \leq P<0,10)$.

${ }^{1} \mathrm{CON}=$ controle voer eenmaal/dag, TAD = twice-a-day-feeding: controle voer tweemaal/dag, $\mathrm{SF}=$ split-feeding tweemaal/dag.

Het eigewicht van de controle en twice-a-day-feeding dieren was hoger dan van de split-feeding dieren, maar er was geen effect van voerstrategie op soortelijk gewicht (Tabel 13).

Het eigewicht nam toe bij toenemende leeftijd, terwijl het soortelijk gewicht af nam.

Tabel 13 Effecten van de verschillende voerstrategieën en leeftijden op eigewicht $(g)$ en soortelijk gewicht.

\begin{tabular}{|c|c|c|}
\hline Item $^{1}$ & Eigewicht (g) & Soortelijk gewicht \\
\hline \multicolumn{3}{|l|}{ Voerstrategie $^{1}$} \\
\hline CON & $66,6^{a}$ & 2,97 \\
\hline TAD & $66,8^{a}$ & 2,87 \\
\hline SF & $66,1^{b}$ & 2,88 \\
\hline SEM & 0,19 & 0,044 \\
\hline \multicolumn{3}{|l|}{ Leeftijd } \\
\hline 45 wk & $65,3^{d}$ & $3,00^{\mathrm{a}}$ \\
\hline $50 \mathrm{wk}$ & $65,6^{\mathrm{cd}}$ & $3,11^{\mathrm{a}}$ \\
\hline $55 \mathrm{wk}$ & $66,2^{c}$ & $2,96^{\mathrm{a}}$ \\
\hline $60 w k$ & $67,1^{\mathrm{b}}$ & $2,74^{b}$ \\
\hline $65 w k$ & $68,1^{a}$ & $2,74^{b}$ \\
\hline SEM & 0,24 & 0,057 \\
\hline \multicolumn{3}{|l|}{$P$-waarde } \\
\hline Voerstrategie & 0,020 & 0,24 \\
\hline Leeftijd & $<0,001$ & $<0,001$ \\
\hline Voerstr*Leeftijd & 0,56 & 0,58 \\
\hline
\end{tabular}

\subsection{Bevedering}

De verschillende voerstrategieën hadden, op het dijbeen na, geen effect op de bevedering van de dieren (Tabel 14). De leeftijd was wel van invloed op de bevedering van de dieren. In het algemeen nam de bevedering af bij het ouder worden (tot 60 weken leeftijd) terwijl de bevedering op 65 weken leeftijd verbeterd was. 
Tabel 14 Effecten van de verschillende voerstrategieën en leeftijden op bevederingsscore

\begin{tabular}{|c|c|c|c|c|c|c|c|c|}
\hline Item $^{1}$ & Nek & Borst & Buik & Rug & Vleugels & Staart & Dijbeen & Gemiddeld \\
\hline \multicolumn{9}{|l|}{ Voerstrategie 1} \\
\hline CON & 1,17 & 3,44 & 3,34 & 3,21 & 2,45 & 2,88 & $2,91^{\mathrm{b}}$ & 2,77 \\
\hline TAD & 1,34 & 3,49 & 3,37 & 3,12 & 2,46 & 2,95 & $2,99^{\mathrm{b}}$ & 2,82 \\
\hline SF & 1,29 & 3,40 & 3,41 & 3,25 & 2,44 & 2,93 & $3,22^{a}$ & 2,85 \\
\hline SEM & 0,064 & 0,073 & 0,070 & 0,096 & 0,414 & 0,068 & 0,071 & 0,052 \\
\hline \multicolumn{9}{|l|}{ Leeftijd } \\
\hline 45 wk & $1,07^{c}$ & $3,37^{b}$ & $2,88^{c}$ & $2,63^{d}$ & $2,37^{b}$ & $2,43^{c}$ & $2,43^{d}$ & $2,45^{d}$ \\
\hline $50 \mathrm{wk}$ & $1,30^{\mathrm{ab}}$ & $3,07^{c}$ & $3,05^{c}$ & $3,00^{c}$ & $2,41^{\mathrm{b}}$ & $2,90^{\mathrm{b}}$ & $2,85^{c}$ & $2,65^{c}$ \\
\hline 55 wk & $1,38^{\mathrm{a}}$ & $3,56^{a b}$ & $3,52^{\mathrm{b}}$ & $3,29^{b}$ & $2,38^{b}$ & $3,03^{a b}$ & $3,14^{\mathrm{b}}$ & $2,90^{\mathrm{b}}$ \\
\hline $60 \mathrm{wk}$ & $1,45^{\mathrm{a}}$ & $3,59^{c}$ & $3,70^{\mathrm{a}}$ & $3,72^{\mathrm{a}}$ & $2,66^{a}$ & $3,13^{a}$ & $3,43^{a}$ & $3,10^{\mathrm{a}}$ \\
\hline 65 wk & $1,13^{\mathrm{bc}}$ & $3,62^{c}$ & $3,70^{\mathrm{a}}$ & $3,33^{\mathrm{b}}$ & $2,44^{\mathrm{b}}$ & $3,11^{\mathrm{a}}$ & $3,33^{a}$ & $2,95^{\mathrm{b}}$ \\
\hline SEM & 0,077 & 0,075 & 0,071 & 0,094 & 0,414 & 0,074 & 0,070 & 0,049 \\
\hline \multicolumn{9}{|l|}{$P$-waarde } \\
\hline Voerstrategie & 0,13 & 0,66 & 0,81 & 0,63 & 0,97 & 0,53 & 0,009 & 0,59 \\
\hline Leeftijd & $<0,001$ & $<0,001$ & $<0,001$ & $<0,001$ & 0,002 & $<0,001$ & $<0,001$ & $<0,001$ \\
\hline Voerstr*Leeftijd & 0,30 & 0,73 & 0,58 & 0,53 & 0,094 & 0,72 & 0,46 & 0,38 \\
\hline
\end{tabular}

$a, b, c, d$ Verschillende letters geven een significant verschil aan $(P \leq 0,05)$.

${ }^{1} \mathrm{CON}=$ controle voer eenmaal/dag, TAD = twice-a-day-feeding: controle voer tweemaal/dag, SF = split-feeding tweemaal/dag.

\subsection{Gedrag}

\subsubsection{Algemeen}

De resultaten van de gedragswaarnemingen op de verschillende leeftijden staan vermeld in Tabel 15. De controle dieren vertoonden een tendens tot meer drinken dan de twice-a-day-feeding dieren, terwijl de drinktijd van split-feeding dieren niet verschilde van die in de andere behandelingen $(P=$ $0,08)$. De tweemaal daags gevoerde dieren (twice-a-day-feeding en split-feeding) stonden meer dan de controle dieren $(P<0,001)$. De controle dieren vertoonden een tendens tot meer zitgedrag dan de split-feeding dieren, terwijl de mate van zitten van de twice-a-day-feeding dieren niet verschilde van die in de andere behandelingen $(P=0,08)$. De twice-a-day-feeding dieren vertoonden een tendens tot meer lopen dan de controle dieren, terwijl de tijd voor lopen van de split-feeding dieren niet verschilde van die van de andere behandelingen $(P=0,06)$. De controle dieren foerageerden meer dan de tweemaal daags gevoerde dieren $(P<0,001)$. De controle dieren vertoonden een tendens tot meer stofbaden dan de split-feeding dieren, terwijl de tijd voor stofbaden van de twice-a-day-feeding dieren niet verschilde van die van de andere behandelingen. 
Effecten van de verschillende voerstrategieën en leeftijden op het gedrag van de hennen (in percentage dieren)

\begin{tabular}{|c|c|c|c|c|c|c|c|c|c|c|c|}
\hline Behandeling ${ }^{1}$ & Eten & $\begin{array}{l}\text { Drin- } \\
\text { ken }\end{array}$ & Staan & Zitten & Lopen & $\begin{array}{l}\text { Foera- } \\
\text { geren }\end{array}$ & Comfort & $\begin{array}{c}\text { Stof } \\
\text { baden }\end{array}$ & $\begin{array}{l}\text { Object } \\
\text { pikken }\end{array}$ & $\begin{array}{c}\text { Agressief } \\
\text { pikken }\end{array}$ & $\begin{array}{c}\text { Ei } \\
\text { leggen }\end{array}$ \\
\hline \multicolumn{12}{|l|}{ Voerstrategie $^{1}$} \\
\hline CON & 22,0 & $8,9^{x}$ & $26,6^{b}$ & $15,7^{x}$ & $4,1^{y}$ & $13,7^{a}$ & 5,4 & $1,7^{x}$ & 0,5 & 0,9 & 0,4 \\
\hline TAD & 21,0 & $7,8^{y}$ & $32,7^{a}$ & $13,4^{x y}$ & $4,9^{x}$ & $11,5^{\mathrm{b}}$ & 6,1 & $1,2^{x y}$ & 0,3 & 0,8 & 0,3 \\
\hline SF & 21,2 & $8,2^{x y}$ & $34,0^{a}$ & $12,4^{y}$ & $4,4^{x y}$ & $11,1^{\mathrm{b}}$ & 5,7 & $1,1^{y}$ & 0,5 & 1,0 & 0,3 \\
\hline SEM & 1,22 & 0,51 & 1,45 & 1,38 & 0,22 & 0,90 & 0,26 & 0,19 & 0,10 & 0,09 & 0,05 \\
\hline \multicolumn{12}{|l|}{ Leeftijd } \\
\hline $45 w k$ & $24,9^{a}$ & $7,9^{\mathrm{bc}}$ & $26,5^{c}$ & $18,0^{a}$ & $4,6^{\mathrm{b}}$ & $11,1^{\mathrm{bc}}$ & $4,5^{b}$ & $1,1^{y}$ & $0,3^{b}$ & 0,9 & $0,2^{\mathrm{b}}$ \\
\hline $50 w k$ & $23,3^{a}$ & $8,3^{\mathrm{b}}$ & $32,1^{\mathrm{ab}}$ & $13,0^{\mathrm{b}}$ & $5,3^{a}$ & $10,5^{\mathrm{cd}}$ & $5,2^{b}$ & $1,0^{y}$ & $0,3^{b}$ & 0,8 & $0,3^{a b}$ \\
\hline 55 wk & $18,6^{b}$ & $7,2^{c}$ & $35,2^{a}$ & $10,3^{c}$ & $3,4^{c}$ & $16,9^{a}$ & $5,4^{b}$ & $1,4^{x y}$ & $0,3^{b}$ & 1,1 & $0,3^{a b}$ \\
\hline $60 w k$ & $19,3^{b}$ & $9,2^{a}$ & $32,0^{a b}$ & $12,2^{\mathrm{bc}}$ & $4,2^{b}$ & $12,6^{b}$ & $7,0^{\mathrm{a}}$ & $1,5^{x y}$ & $0,7^{a}$ & 0,9 & $0,5^{a}$ \\
\hline 65 wk & $21,1^{\mathrm{ab}}$ & $8,9^{\mathrm{ab}}$ & $29,7^{\mathrm{bc}}$ & $15,9^{a}$ & $4,9^{b}$ & $9,3^{d}$ & $6,6^{a}$ & $1,7^{x}$ & $0,5^{a b}$ & 1,1 & $0,4^{a}$ \\
\hline SEM & 1,57 & 0,53 & 1,64 & 1,33 & 0,26 & 0,96 & 0,34 & 0,23 & 0,12 & 0,12 & 0,07 \\
\hline \multicolumn{12}{|l|}{$P$-waarde } \\
\hline Voerstrategie & 0,82 & 0,080 & $<0,001$ & 0,079 & 0,056 & $<0,001$ & 0,17 & 0,076 & 0,14 & 0,33 & 0,66 \\
\hline \multirow[t]{2}{*}{ Leeftijd } & & $<0,00$ & $<0,001$ & $<0,001$ & $<0,001$ & $<0,001$ & $<0,001$ & 0,11 & 0,01 & 0,34 & 0,047 \\
\hline & 0,022 & 1 & & & & & & & & & \\
\hline Voerstr*Leeft & 0,91 & 0,65 & 0,93 & 0,75 & 0,66 & 0,49 & 0,43 & 0,27 & 0,25 & 0,86 & 0,22 \\
\hline
\end{tabular}

\subsubsection{Gedragspatroon}

In Figuur 7 zijn de verschillende soorten gedrag (eten, drinken, staan, zitten, lopen, foerageren, comfort, stofbad, object pikken en kip pikken) gedurende de dag grafisch weergegeven.

Voor de verschillende gedragingen werden significante interacties gevonden tussen de voerstrategie en observatieronden gedurende de dag. In het algemeen was het gedragspatroon van de tweemaal per dag gevoerde dieren vergelijkbaar en daarom worden de verschillen tussen eenmaal (CON) en tweemaal (TAD en SF) per dag voeren besproken. In het algemeen vertoonden de dieren die tweemaal per dag werden gevoerd een duidelijk ander eetpatroon dan de dieren die eenmaal per dag gevoerd werden. Tijdens de tweede observatieronde, na de eerste keer voer verstrekken ( 07.30 uur), stonden gemiddeld circa $75 \%$ van de dieren te eten. Bij de eenmaal per dag gevoerde dieren nam dit gedurende de dag langzaam af naar ongeveer $6 \%$ tussen de $10^{\mathrm{e}}$ en $12^{\mathrm{e}}$ observatieronde. Bij de tweemaal per dag gevoerde dieren nam het percentage dieren sneller af en lag tussen de $8^{\mathrm{e}}$ en $10^{\mathrm{e}}$ observatieronde rond de $2 \%$. Na de tweede maal voeren was ruim $80 \%$ van de dieren aan het eten, waarna het snel afnam. 

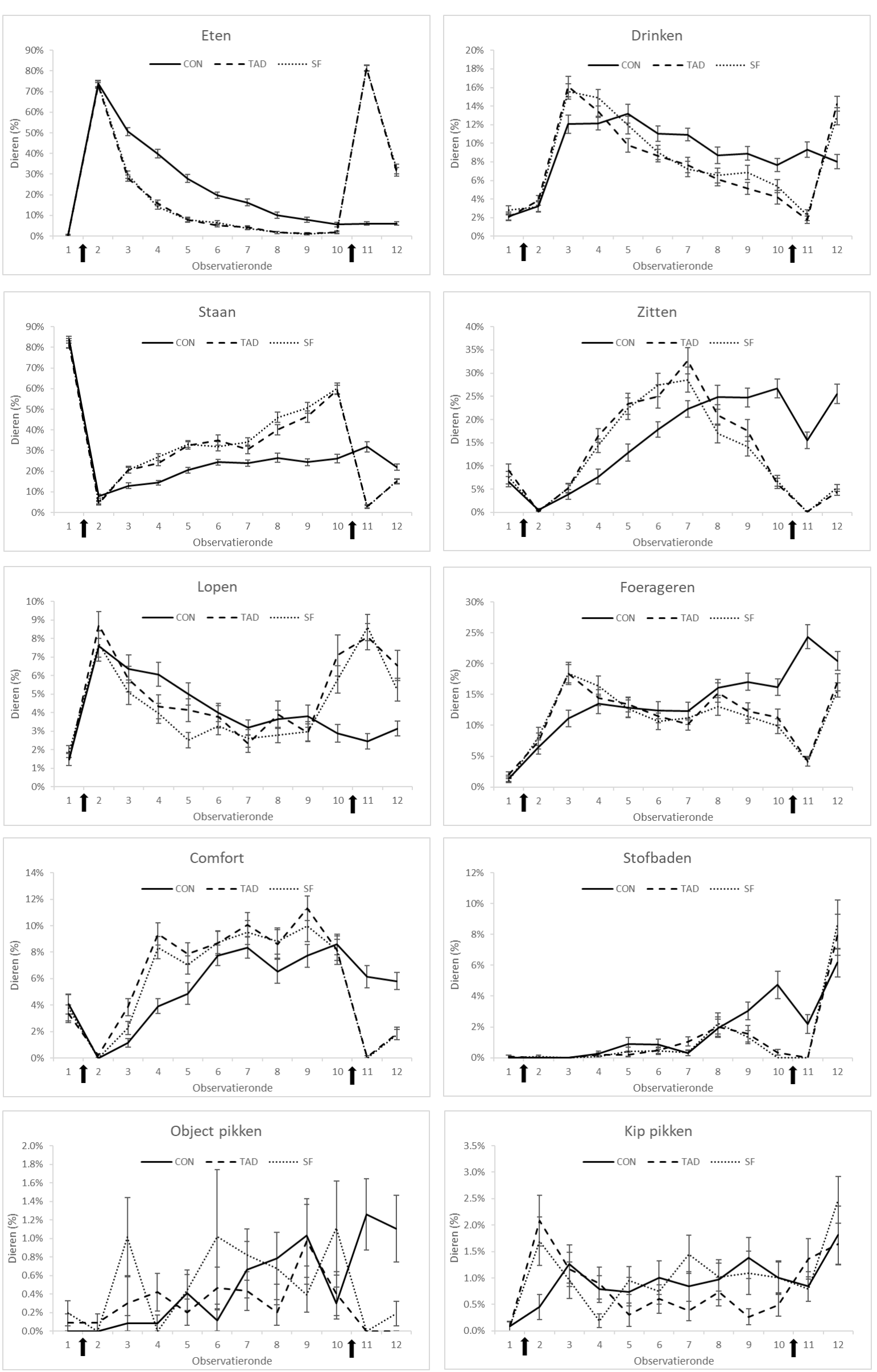

Figuur 7 Effect van voerstrategie op ontwikkeling verschillende gedragingen gedurende de dag. Pijlen geven het moment van voeren aan (1 $1^{e}: 07: 30$ uur en $2^{e}: 16: 00$ uur). 
Ondanks dat de dieren tijdens de $1^{\mathrm{e}}$ observatieronde toegang tot water hadden was slechts $2 \%$ van de dieren dan aan het drinken. Nadat het voer verstrekt was, waren nauwelijks dieren (3-4\%) aan het drinken. Dit percentage was echter flink hoger tijdens de derde observatieronde. De dieren die tweemaal daags gevoerd werden vertoonden meer drinken tijdens de $3^{\mathrm{e}}$ observatieronde en vanaf de $5^{\mathrm{e}}$ ronde minder drinkgedrag. Bij de laatste observatieronde waren er van de dieren die tweemaal per dag gevoerd werden meer dieren aan het drinken.

Direct nadat het licht aan was gegaan en voor het voeren stonden de meeste dieren (ruim 80\%). De dieren die tweemaal per dag gevoerd werden, vertoonden gedurende de dag steeds meer staan gedrag. Het nam vanaf observatieronde 2 naar 10 toe van circa 5 naar $60 \%$ van de dieren. Na de tweede voerbeurt was het percentage dieren dat stond flink lager. De dieren die eenmaal per dag gevoerd werden, vertoonden gedurende de dag een lichte stijging in staan van circa 10 tot $30 \%$. Vlak voor het verstrekken van de eerste voerbeurt zat circa $8 \%$ van de dieren op het strooisel of rooster. Na de eerste voerbeurt waren er nauwelijks dieren die zaten, waarna het percentage bij de tweemaal per dag gevoerde dieren snel toenam van circa 0 naar $30 \%$ tussen de $2^{\mathrm{e}}$ en $7^{\mathrm{e}}$ observatieronde. Daarna nam het percentage weer snel af, van circa 30 naar $0 \%$ tussen de $7^{\mathrm{e}}$ en $11^{\mathrm{e}}$ observatieronde. Het zitgedrag nam bij de eenmaal per dag gevoerde dieren tussen de $2^{\mathrm{e}}$ en $8^{\mathrm{e}}$ observatieronde lineair toe tot circa $25 \%$ om daarna, op één dip na tijdens de $11^{\mathrm{e}}$ observatieronde, te stabiliseren.

Voor de eerste voerbeurt werd er nauwelijks gelopen door zowel de dieren die eenmaal als tweemaal per dag gevoerd werden. Na de eerste voerbeurt nam het lopen lineair af voor alle behandelingen en stabiliseerde rond de $3 \%$ tussen de $7^{\mathrm{e}}$ en $12^{\mathrm{e}}$ ronde voor de eenmaal per dag gevoerde dieren. De tweemaal per dag gevoerde dieren lieten een opleving zien van loop gedrag tussen de $10^{\mathrm{e}}$ en $12^{\mathrm{e}}$ observatieronde.

De tweemaal per dag gevoerde dieren foerageerden tijdens de $3^{\mathrm{e}}$ ronde meer en tussen de $9^{\mathrm{e}}$ en $12^{\mathrm{e}}$ ronde minder dan de eenmaal per dag gevoerde dieren.

De dieren die tweemaal per dag gevoerd werden vertoonden tussen de $3^{\mathrm{e}}$ en $5^{\mathrm{e}}$ ronde en de $9^{\mathrm{e}}$ ronde meer comfort gedrag, terwijl ze na de tweede voerbeurt minder comfort gedrag vertoonden dan de dieren die eenmaal per dag gevoerd werden.

Gedurende de dag was er geen verschil in stofbadgedrag. Alleen rond de tweede voerbeurt (tussen de $9^{\mathrm{e}}$ en $11^{\mathrm{e}}$ ronde) vertoonden de tweemaal per dag gevoerde dieren minder stofbad gedrag.

De dieren die tweemaal per dag werden gevoerd vertoonden na de tweede voerbeurt $\left(11^{\mathrm{e}}\right.$ en $12^{\mathrm{e}}$ ronde) minder object pikgedrag dan de eenmaal per dag gevoerde dieren.

De tweemaal per dag gevoerde dieren vertoonden meer pikgedrag naar andere kippen tijdens de $2^{\mathrm{e}}$ observatieronde. 


\section{Discussie}

\subsection{Effect voerstrategieën op productieresultaten}

De split-feeding dieren vertoonden een tendens tot een gemiddeld ruim $2 \%$ hoger legpercentage gedurende de gehele experimentele periode. Dit is in overeenstemming met onderzoek van van Emous et al. (2020) en Trouw (2021), die ook split-feeding toepasten bij ouderdieren. Van Emous et al. (2020) vonden een 3,2\% hoger legpercentage $(P=0,088)$ tussen 51 en 55 weken leeftijd bij splitfeeding ten opzichte van controle dieren. Tussen 50 en 60 weken leeftijd vonden zij een numeriek hoger legpercentage $(73,1$ vs. $70,0 \% ; P=0,13)$ voor de split-feeding ten opzichte van de controle dieren. In het onderzoek van Trouw (2021) vonden de onderzoekers een significant hoger legpercentage tussen 55 en 60 weken leeftijd, wat resulteerde in meer eieren en meer kuikens. Bij een onderzoek uitgevoerd door Trouw (2021) in samenwerking met een grote Spaanse integratie bij meer dan 120.000 ouderdieren vonden zij een 1,9 hogere kuiken productie.

De dieren die de twice-a-day-feeding voerstrategie volgden hadden geen aantoonbaar hoger legpercentage dan de dieren die de controle voerstrategie volgden. Dit is in overeenstemming met onderzoek van Cave (1981), Bootwalla et al. (1983), Samara et al. (1996) en Backhouse en Gous (2005) die ook geen verschillen vonden bij verschillende voertijden en twice-a-day-feeding. Dit echter in tegenstelling tot onderzoek van de Avila et al. (2003), Spradley et al. (2008), Taherkhani et al. (2010), Moradi et al. (2013) en Soltanmoradi et al. (2013) die wel een hogere eiproductie vonden bij twice-a-day-feeding in vergelijking met eenmaal daags gevoerde dieren.

De dieren die tweemaal per dag gevoerd werden dronken minder en hadden een lagere water/voerverhouding dan de dieren die eenmaal per dag gevoerd werden. Dit wordt onderbouwd door de gedragsobservaties, waarbij een lager percentage dieren werd gezien dat drinkgedrag vertoonde. De reden voor het verschil in wateropname is niet goed duidelijk maar heeft mogelijk te maken met het verdelen van de voerhoeveelheid over twee porties gedurende de dag. De dieren waren rustiger en de wateropname was mogelijk meer naar de behoefte aan water door de spreiding van de voerbeurten.

Er werden geen effecten van tweemaal daags voeren (twice-a-day-feeding en split-feeding) op het eigewicht gevonden, wat in overeenstemming is met het onderzoek van Samara et al. (1996) en Harms (1991) die ook twice-a-day-feeding toepasten. Anderzijds vonden Cave (1981), Spradley et al. (2008) en Moradi et al. (2013) wel hogere eigewichten wanneer ouderdieren twee- of driemaal per dag gevoerd werden.

De uitval bij de dieren met het split-feeding programma was lager dan bij de dieren met het twice-aday-feeding programma. Er is geen informatie met betrekking tot uitval gevonden in de literatuur bij onderzoek gericht op split-feeding en twice-a-day-feeding. Er werden geen verschillen gevonden in het voorgaande onderzoek (van Emous, persoonlijke mededeling). De reden voor de verschillen in uitval zijn niet duidelijk, maar het kan zijn dat door het beter afstemmen van de nutriënten gedurende de dag de weerstand beter ondersteund wordt waardoor uitval voorkomen wordt.

In het algemeen was de uitval in het huidige experiment hoger dan gebruikelijk in experimenten en zelfs tweemaal zo hoog als in de praktijk (Aviagen, 2021). Deze hoge uitval kwam doordat de uitval bij het praktijkbedrijf ook al aan de hoge kant was. Een klein gedeelte van de dieren (21\%) werd daadwerkelijk dood aangetroffen. Het resterende gedeelte van de uitval (79\%) werd veroorzaakt door selectie van niet leggende (38\%), kreupele (23\%) en verwonde (vooral flank) (18\%) dieren. Dit hoge aantal uitgeselecteerde dieren komt door de strenge welzijnseisen tijdens experimenten. Dieren die een afwijking hebben worden vaak preventief verwijderd om verminderd welzijn te voorkomen. 


\subsection{Effect voerstrategie op broederijresultaten}

Er werden geen effecten van de verschillende voerstrategieën gevonden op broederijresultaten, wat overeenkomt met het onderzoek van Spradley et al. (2008). Daarentegen vonden Soltanmoradi et al. (2013) dat twice a day-feeding een hogere bevruchting en uitkomst gaf. Opgemerkt wordt dat in het onderhavige experiment de eieren slechts tot zeven dagen werden gebroed en geen informatie kon worden verzameld over het resterende deel van broedperiode ( 7 tot 21 dagen).

\subsection{Effect voerstrategie op broedeikwaliteit}

Er werden geen verschillen op broedeikwaliteit (percentage breuk-/kneus-/windeieren, breuksterkte, eischaaldikte, eischaalgewicht en droge stofgehalte eischaal) tussen de voerstrategieën aangetroffen. In het onderzoek van Trouw (2021) vond men echter wel positieve effecten van split-feeding op de eischaal kwaliteit. Men vond een hoger eischaalgewicht en een tendens tot een hoger schaalgewicht per oppervlakte $\left(\mathrm{mg} / \mathrm{cm}^{2}\right)$.

De eieren van de dieren die volgens het split-feeding programma gevoerd werden hadden het laagste albumen percentage en het hoogste dooier percentage. Dit is mogelijk ontstaan door het lagere eiwitgehalte en hogere energiegehalte in het ochtendvoer. De albumen/dooier verhouding was hoger bij de eieren van de twice-a-day-feeding dieren ten opzichte van de eieren van de controle en splitfeeding dieren.

\subsection{Effect voerstrategie op bevedering}

Er werden geen verschillen in de kwaliteit van de bevedering waargenomen tussen de verschillende voerstrategieën. De kwaliteit van de bevedering nam, zoals verwacht, af in de tijd om na 60 weken leeftijd weer iets te verbeteren. Dit kwam doordat enkele dieren spontaan in de rui kwamen en een betere bevedering ontwikkelden. Tijdens de laatste beoordeling van de bevedering, op 65 weken leeftijd, is een inschatting gemaakt van het aantal dieren dat geruid had. Er was geen verschil in het percentage geruide dieren tussen de behandelingen maar gemiddeld over alle behandelingen had circa $10 \%$ van de dieren geruid.

\subsection{Effect voerstrategie op gedrag}

In het huidige experiment was er geen verschil in eetgedrag terwijl in het vorige experiment de tweemaal per dag gevoerde dieren juist meer eetgedrag vertoonden. De twice-a-day feeding dieren vertoonden een tendens tot minder drinkgedrag dan de controle dieren terwijl de split-feeding dieren niet verschilde van de andere voerstrategieën. In het voorgaande experiment werden geen verschillen gevonden in drinkgedrag (van Emous et al., 2020). De tweemaal daags gevoerde dieren (twice-a-dayfeeding en split-feeding) vertoonden meer stagedrag dan de controle dieren $(P<0,001)$ terwijl er in het voorgaande experiment (van Emous et al., 2020) geen verschillen werden gevonden. In het huidige experiment vertoonden de controle dieren een tendens tot meer zitten terwijl in het vorige experiment deze dieren juist minder zitgedrag vertoonden. De twice-a-day-feeding dieren vertoonden een tendens tot meer lopen dan de controle dieren terwijl het loopgedrag van de split-feeding dieren niet verschilde van dat in de andere behandelingen. In het vorige experiment was er geen verschil tussen de voerstrategieën ten aanzien van lopen. De tweemaal per dag gevoerde dieren foerageerden minder dan de controle gevoerde dieren, wat in overeenstemming is met het vorige experiment. In zowel het huidige als het voorgaande experiment werden geen verschillen gevonden in comfort gedrag. De controle dieren vertoonden een tendens tot meer stofbaden dan de split-feeding dieren terwijl het stofbadgedrag van de twice-a-day-feeding dieren niet verschilde van dat van de andere behandelingen. In het vorige experiment werden geen verschillen gevonden tussen de voer strategieën op stofbadgedrag. In het huidige experiment werden geen verschillen gevonden in object- 
en kip pikken, terwijl in het vorige experiment de tweemaal per dag gevoerde dieren minder objectpikken vertoonden.

De verschillen in het vertoonde gedrag tussen beide experimenten komt mogelijk door de verschillen in herkomst. De dieren in het vorige experiment waren al vanaf eendagskuiken aanwezig in de hokken terwijl de dieren in het huidige experiment afkomstig waren uit een praktijkstal.

De tweemaal per dag gevoerde dieren (twice-a-day-feeding en split-feeding) vertoonden een duidelijk ander gedragspatroon dan de eenmaal per dag gevoerde dieren. Doordat de dieren die tweemaal per dag gevoerd werden maar een halve portie voer kregen in de ochtend was het voer sneller op dan bij de eenmaal per dag gevoerde dieren. Dit gegeven is de belangrijkste factor ten aanzien van de verschillen in gedragspatronen tussen de eenmaal en tweemaal gevoerde dieren. Doordat de dieren die tweemaal per dag gevoerd werden minder tijd besteedden aan voer opnemen vertoonden ze ook minder drinkgedrag. Daarnaast waren ze relatief meer aan het rusten (staan en zitten) en vertoonden ze meer comfort gedrag gedurende de dag. Dit komt overeen met het vorige onderzoek van van Emous et al. (2020). 


\section{$5 \quad$ Conclusies}

Uit het onderzoek blijkt dat de dieren die het split-feeding programma volgden een hogere productie en lagere uitval hadden tussen 45 en 65 weken leeftijd. Daarnaast werden een lagere wateropname en water/voer-verhouding gevonden bij de tweemaal daags gevoerde dieren (twice-a-day-feeding en split-feeding). Verder had het toepassen van tweemaal daags voeren (twice-a-day-feeding en splitfeeding) nauwelijks effecten op reproductie en broedeikwaliteit en geen effect op broederijresultaten.

Het was niet helemaal eenduidig maar de tweemaal daags gevoerde dieren vertoonden in het algemeen gemiddeld minder drinken, meer staan, minder zitten, meer lopen en minder foerageren. Bij de tweemaal ten opzichte van eenmaal daags gevoerde dieren werd een ander gedragspatroon gedurende de dag waargenomen. De tweemaal daags gevoerde dieren kregen tweemaal daags een halve portie voer, hetgeen de belangrijkste factor was voor de verschillen in het gedragspatroon. 


\section{Literatuur}

Aviagen-EPI. 2017. Managementgids Ross 308 ouderdieren. Roermond, Nederland.

Aviagen. 2021. European parent stock Ross 308 performance objectives. USA.

Backhouse, D., Gous, R.M. 2005. The effect of feeding time on shell quality and oviposition time in broiler breeders. Br. Poult. Sci. 46:255-259.

Backhouse, D., Gous, R.M. 2006. Responses of adult broiler breeders to feeding time. Worlds Poult. Sci. J. 62:269-281.

Barna, J., Végi, B., Váradi, É., Szőke, Zs., Péczely, P. 2009. Studies related to fertility in broiler breeders. XXI. International Poultry Symposium PB WPSA, Wroclaw-Szklarska Poreba, Poland, September 2009. pp. 18-23.

Bilcik, B., Keeling., L.J. 1999. 'Changes in Feather Condition in Relation to Feather Pecking and Aggressive Behaviour in Laying Hens'. Br. Poult. Sci. 40:444-51.

Bootwalla, S.M., Wilson, H.R., Harms, R.H. 1983. Performance of broiler breeders on different feeding systems. Poult. Sci. 62:2321-2325.

Brake, J., 1985. Relationship of egg weight, specific gravity, and shell weight to time of oviposition and feeding in broiler breeders. Poult. Sci. 64:2037-2040.

Casanovas, P. 2000. Management techniques to improve male mating activity and compensate for the age-related decline in broiler breeder fertility: intra-spiking. Cobb-Vantress Technical News.

Casanovas, P. 2002. Management techniques to improve male mating activity and compensate for the age-related decline in broiler breeder fertility: intraspiking. Poult. Inf. Professional 63:1-13.

Cave, N.A., 1981. Effect of diurnal programs of nutrient intake on the performance of broiler breeder hens. Poult. Sci. 60:1287-1292.

de Avila, V.S., Penz Jr., A.M., De Brum, P.A.R., Rosa, P.S., Guidoni, A.L., De Figueiredo, É.A.P. 2003. Performance of female broiler breeders submitted to different feeding schedules. Br. J. Poult. Sci. 5:197-201.

de Jong, I.C., A. Lourens, H. Gunnink and R.A. Van Emous. 2011. Effect van bezettingsdichtheid op (de ontwikkeling van) het paargedrag en de technische resultaten bij vleeskuikenouderdieren. 61 p. Wageningen UR Livestock Research, Lelystad, Report 457.

de Los Mozos, J., Sanchez. F. 2014. Split feeding meets layers' specific needs. http://www.thepoultrysite.com/articles/3091/split-feeding-system-for-more-sustainable-eggproduction.

Duncan, I.J.H., Hocking, P.M., Seawright, E.. 1990. Sexual behaviour and fertility in broiler breeder domestic fowl. Appl. Anim. Behav. Sci. 26:201-213.

Farmer, M., Roland Sr., D.A., Brake, J., Eckman, M.K. 1983a. Calcium metabolism in broiler breeder hens. 1. Calcium status of the digestive tract of broiler breeders throughout a 24 hour period. Poult. Sci. 62:459-464.

Farmer, M., Roland Sr., D.A., Eckman, M.K. 1983b. Calcium metabolism in broiler breeder hens. 2. The influence of the time of feeding on calcium status of the digestive system and egg shell quality in broiler breeders. Poult. Sci. 62:465-471.

Sarabia Fragoso, J.S., Pizarro Díaz, M., Abad Moreno, J.C., Casanovas Infesta, P., Rodriguez-Bertos, A., Barger, K. 2013. Relationships between fertility and some parameters in male broiler breeders (body and testicular weight, histology and immunohistochemistry of testes, spermatogenesis and hormonal levels). Reprod. Dom. Anim. 48:345-352.

Gauthier, R. 2002. La salud intestinal: clave de la productividad (El caso de los Ácidos Orgânicos). In: Precongreso Cientifico Avicola IASA, XXVIIConvencion ANECAWPDC. Anais eletrônicos, Puerto Vallarta, Jal. Méxicohttp://www.engormix.com/MA-avicultura/nutricion/articulos/salud-intestinalclave-productividad-t518/p0.htm [Accessed 8.8.13].

Genstat. 2018. Genstat 19th Reference Manual: Release 1. Clarendon Press, Oxford, UK.

Harms, R.H., 1991. The influence of changing time of feeding on performance of broiler breeder hens. Poult. Sci. 70:1695-1698.

Harris, G.C., jr, Benson, J., Sellers, T.A., Cole, T.A. 1980. The mating activity of broiler breeder cockerels. Arkansas Farm Res. 29:15. 
Londero, A., Rosa, A.P., Giacomini, C.B.S., Vivas, C.E.B., Orso, C., de Freitas, H.M., Gressler, L.T., Vargas, A.C. 2015. Effect of different feeding schedules on reproductive parameters and egg quality of broiler breeders. Anim. Feed Sci. Tech. 210:165-171.

Mols, M.C.P. 1978. Paringsactiviteit van hanen onder verschillende huisvestingssystemen. Intern rapport 1178P. Het Spelderholt, Beekbeekbergen.

Moradi, S., Zaghari, M., Shivazad, M., Osfoori, R., Mardi, M. 2013. The effect of increasing feeding frequency on performance, plasma hormones and metabolites, and hepatic lipid metabolism of broiler breeder hens. Poult. Sci. 92:1227-1237.

Roland Sr., D.A., Farmer, M. 1984. Egg shell quality II: importance of time of calcium intake with emphasis on broiler breeders. Worlds Poult. Sci. J. 40:255-260.

Samara, M.H., Robbins, K.R., Smith, M.O. 1996. Interaction of feeding time and temperature and their relationship to performance of the broiler breeder hen. Poult. Sci. 75:34-41.

Soltanmoradi, M.G., Seidavi, A., Dadashbeiki, M., Delgado, F., Gamboa, S. 2013. Effect of time, amount and frequency of feeding on total egg production, fertility and hatchability in broiler breeders. Arch. Tierzucht: Arch. Anim. Breed. 56:102.

Spradley, J.M., Freeman, M.E., Wilson, J.L., Davis, A.J. 2008. The influence of a twice-a-day feeding regimen after photostimulation on the reproductive performance of broiler breeder hens. Poult. Sci. 87:561-568.

Taherkhani, R., Zaghari, M., Shivazad, M., Zare Shahneh, A. 2010. A twice-a-day feeding regimen optimizes performance in broiler breeder hens. Poult. Sci. 89:1692-1702.

Trouw. 2021. Innovative split-feeding system for broiler breeders. International Hatchery Practice 35: 7-9.

van Emous, R.A., Kwakkel, R.P., van Krimpen, M.M., Hendriks, W.H. 2015. Effects of different dietary protein levels during rearing and different dietary energy levels during lay on behaviour and feather cover in broiler breeder females. Appl. Anim. Behav. Sci. 168:45-55.

van Emous, R.A., Mens, A.J.W., Binnendijk, G.P. 2020. Split-feeding en twice a day-feeding bij vleeskuikenouderdieren. Rapport 1272. Wageningen Livestock Research, Wagening.

van Krimpen, M.M., van Binnendijk, G.P., van Emous, R.A. 2018. Effect van split-feeding bij biologisch gehouden leghennen op de fosforexcretie en schaalkwaliteit. Rapport 1120. Wageningen Livestock Research, Wageningen.

Wilson, H.R., Keeling, L.J. 1991. Effect of time of feeding on oviposition time and production parameters in broiler breeders. Poult. Sci. 70:254-259. 


\section{Bijlage 1 Schematisch overzicht hok}

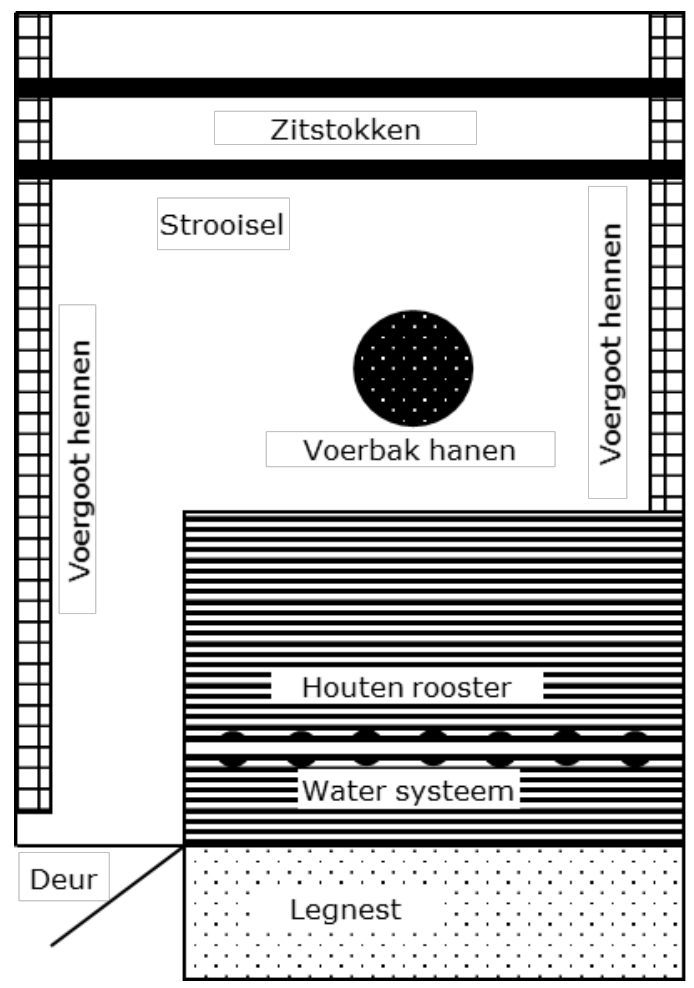




\section{Bijlage 2 Samenstelling voeders}

Controlevoer

Ochtendvoer

Middagvoer

\begin{tabular}{|c|c|c|c|}
\hline \multicolumn{4}{|l|}{ Ingrediënt (g/kg) } \\
\hline Mais & 376,2 & 376,2 & 376,2 \\
\hline Tarwe & 249,9 & 275,8 & 230,3 \\
\hline Tarwegries & 45,8 & 12,4 & 60,0 \\
\hline Raapzaadschroot & 49,5 & 49,5 & 49,5 \\
\hline Sojaschroot & 49,9 & 63,0 & 33,1 \\
\hline Zonnebloemschroot & 79,2 & 80,2 & 80,2 \\
\hline Erwten & 15,0 & 30,0 & 15,0 \\
\hline Sojaolie & 22,9 & 24,1 & 19,9 \\
\hline Zalmolie & 4,0 & 4,0 & 4,0 \\
\hline Salcurb Dry K2 & 5,0 & 5,0 & 5,0 \\
\hline Kalksteentjes (grof) & 65,5 & 11,3 & 84,8 \\
\hline Krijt & 15,0 & 45,3 & 21,0 \\
\hline Mono-cal-fosfaat & 3,2 & 4,2 & 2,2 \\
\hline Natriumbicarbonaat & 3,4 & 3,5 & 3,4 \\
\hline Zout & 1,4 & 1,4 & 1,4 \\
\hline DL-Methionine & 1,1 & 1,2 & 0,9 \\
\hline L-Lysine HCL & 0,9 & 0,8 & 0,9 \\
\hline L-Threonine & 0,6 & 0,7 & 0,5 \\
\hline Choline-chloride & 1,5 & 1,5 & 1,5 \\
\hline Foktoom premix & 4,0 & 4,0 & 4,0 \\
\hline Water & 6,1 & 6,0 & 6,1 \\
\hline \multicolumn{4}{|l|}{ Berekend (g/kg) } \\
\hline OEleg (kcal/kg) & 2.840 & 2.939 & 2.738 \\
\hline OEpl (kcal/kg) & 2.800 & 2.900 & 2.700 \\
\hline Drogestof & 889,5 & 887,0 & 892,1 \\
\hline Ruw as & 111,3 & 88,4 & 135,1 \\
\hline Ruw eiwit & 139,0 & 146,3 & 131,3 \\
\hline Ruw vet & 48,0 & 48,7 & 45,0 \\
\hline C18:2 & 23,6 & 24,0 & 22,0 \\
\hline Ruwe celstof & 41,2 & 40,0 & 41,7 \\
\hline Zetmeel & 409,0 & 425,6 & 399,6 \\
\hline Calcium & 33,5 & 24,2 & 43,1 \\
\hline Fosfor, totaal & 4,46 & 4,61 & 4,25 \\
\hline Fosfor, opneembaar & 3,10 & 3,30 & 2,90 \\
\hline Magnesium & 2,00 & 1,85 & 2,12 \\
\hline Natrium & 1,60 & 1,60 & 1,60 \\
\hline Kalium & 5,99 & 6,12 & 5,75 \\
\hline Chloor & 1,90 & 1,90 & 1,90 \\
\hline $\mathrm{EB}$ (meq) & 169 & 173 & 163 \\
\hline vLysine & 5,30 & 5,70 & 4,90 \\
\hline vMethionine & 3,39 & 3,65 & 3,13 \\
\hline $\mathrm{vM}+\mathrm{C}$ & 5,48 & 5,82 & 5,12 \\
\hline vThreonine & 4,51 & 4,84 & 4,16 \\
\hline vTryptofaan & 1,33 & 1,40 & 1,23 \\
\hline \multicolumn{4}{|l|}{ Geanalyseeerd $(\mathrm{g} / \mathrm{kg})$} \\
\hline Droge stof & 879,0 & 878,0 & 883,0 \\
\hline Ruw as & 98,0 & 86,0 & 125,0 \\
\hline Ruw eiwit & 142,0 & 144,0 & 130,0 \\
\hline Ruw vet & 52,0 & 54,0 & 49,0 \\
\hline Ruwe celstof & 45,0 & 45,0 & 42,0 \\
\hline Calcium totaal & 31,7 & 25,1 & 41,1 \\
\hline Fosfor totaal & 4,13 & 4,58 & 3,97 \\
\hline
\end{tabular}




\section{Bijlage 3 Ethogram gedrag}

\begin{tabular}{||l|l||}
\hline Gedrag & Beschrijving \\
\hline Eten & Pikken naar voer in het voersysteem. \\
\hline Drinken & Pikken naar water in het watersysteem. \\
\hline Staan & Staan zonder uitvoeren van ander gedrag. \\
\hline Litten & Zitten zonder uitvoeren van ander gedrag. \\
\hline Foerageren & Lopen zonder uitvoeren van ander gedrag. \\
\hline Comfort & $\begin{array}{l}\text { Foerageren (pikken naar het strooisel, eventueel afgewisseld met } \\
\text { krabben in het strooisel). }\end{array}$ \\
\hline Stofbaden & $\begin{array}{l}\text { Al het verzorgingsgedrag (zonder stofbaden), zoals verenpoetsen, } \\
\text { zelf pikken, knabbelen, aaien, vleugelslaan en strekken. }\end{array}$ \\
\hline Object pikken & $\begin{array}{l}\text { Stofbaden zonder uitvoeren van ander gedrag. Dit zijn alle } \\
\text { elementen van stofbadgedrag, dus vanaf het inschudden van het } \\
\text { strooisel in de veren tot en met het uitschudden na een cyclus. }\end{array}$ \\
\hline Kip pikken & $\begin{array}{l}\text { Object pikken zonder uitvoeren van ander gedrag. Objecten zijn de } \\
\text { lege voerbak en onderdelen van het hok (maar niet de drinker). }\end{array}$ \\
\hline Ei leggen & Kip pikken zonder uitvoeren van ander gedrag. \\
\hline \hline
\end{tabular}



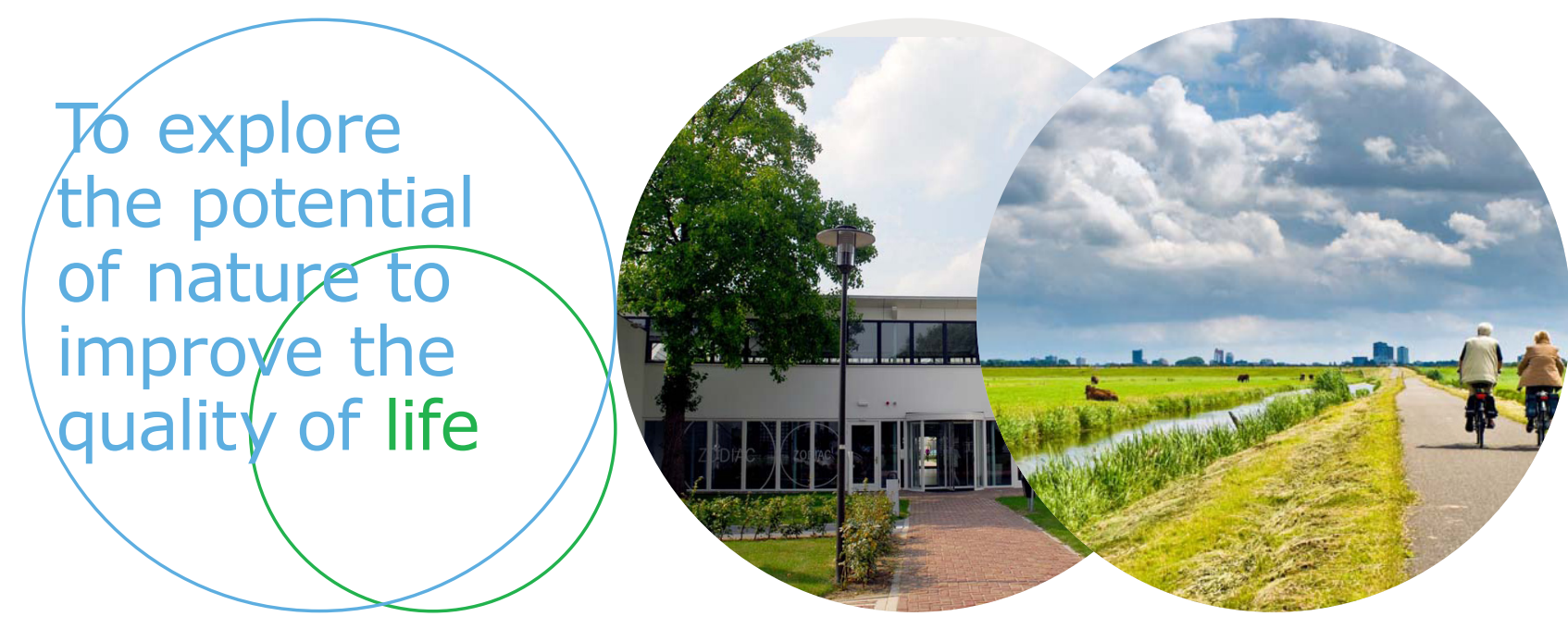

Wageningen Livestock Research Postbus 338

$6700 \mathrm{AH}$ Wageningen

T 0317483953

E info.livestockresearch@wur.nl www.wur.nl/livestock-research
Wageningen Livestock Research ontwikkelt kennis voor een zorgvuldige en renderende veehouderij, vertaalt deze naar praktijkgerichte oplossingen en innovaties, en zorgt voor doorstroming van deze kennis. Onze wetenschappelijke kennis op het gebied van veehouderijsystemen en van voeding, genetica, welzijn en milieu-impact van landbouwhuisdieren integreren we, samen met onze klanten, tot veehouderijconcepten voor de $21 \mathrm{e}$ eeuw.

De missie van Wageningen University \& Research is 'To explore the potential of nature to improve the quality of life'. Binnen Wageningen University \& Research bundelen 9 gespecialiseerde onderzoeksinstituten van Stichting Wageningen Research en Wageningen University hun krachten om bij te dragen aan de oplossing van belangrijke vragen in het domein van gezonde voeding en leefomgeving. Met ongeveer 30 vestigingen, 6.500 medewerkers en 10.000 studenten behoort Wageningen University \& Research wereldwijd tot de aansprekende kennisinstellingen binnen haar domein. De integrale benadering van de vraagstukken en de samenwerking tussen verschillende disciplines vormen het hart van de unieke Wageningen aanpak. 